\title{
Darwin's Conversion: The Beagle Voyage and Its Aftermath
}

\author{
FRANK J. SULLOWAY
}

Department of Psychology and Social Relations

Harvard University

Cambridge, Massachusetts 02138

I feel not a shade of surprise at your entirely rejecting my views: my surprise is that I have been successful in converting some few eminent Botanists, Zoologists, \& Geologists. In several cases the conversion has been very slow $\&$ that is the only sort of conversion which I respect.

- Darwin to an unknown correspondent, March 14, 1861 (de Beer 1958a:112-13)

The issue of how and when Charles Darwin became an evolutionist has long fascinated his biographers. Such historical curiosity is hardly surprising; for, without his own conversion, the orthodox young Darwin who once intended to become a clergyman would never have gone on to inspire the scientific revolution that now bears his name.

Intimately associated with Darwin's conversion is the story of his circumnavigation of the globe as ship's naturalist aboard H.M.S. Beagle (1831-1836). Indeed, the voyage of the Beagle displays all the hallmarks of a heroic tale in the history of science. Young Darwin, a recent Cambridge University graduate and the third person to be offered the position as ship's naturalist, realized the scientific opportunity of a lifetime when he accompanied the Beagle around the world. "The voyage of the Beagle," Darwin asserted in his Autobiography, "has been by far the most important event in my life and has determined my whole career. . . I I have always felt that I owe to the voyage the first real training or education of my mind" (1958[1876]:76-77). For the nearly five years that Darwin was aboard the Beagle, he examined many little-explored regions and collected materials for what subsequently became nine volumes on the geology and natural history of the places

he visited. Further inspired by his Beagle observations and collections, Darwin commenced within ten months of his return to England the first of a series of notebooks on the transmutation of species, a subject on which he never ceased to reflect.

Precisely what scientific ideas Darwin developed during the Beagle 
voyage has been subject to considerable debate. Four different opinions have been advanced in the Darwin literature conceming the specific role that the voyage played in converting him to a transmutationist position: (1) that Darwin left England in 1831 with the evolutionary hypothesis well in mind, applying it to his voyage findings as he went along; ${ }^{1}$ (2) that he began to suspect the possibility of transmutation only during the first or second year of the voyage; ${ }^{2}(3)$ that only after visiting the Galapagos Archipelago, and sometime before his return to England, did he finally embrace the possibility of evolution; ${ }^{3}$ and (4) that he did not finally accept evolution until his retum to England, when he began to prepare his Journal of Researches for publication and saw how many facts tended to support the mutability of species. ${ }^{4}$

Darwin himself was inconsistent on the whole question of his conversion, with the result that authors with differing viewpoints have been able to see somewhere in his writings a confirmation of their own particular views. Darwin's Autobiography, which provides one of the most explicit statements on this subject, merely confirms the impression given by the Introduction to the Origin (1859:1), namely, that he became more and more convinced of the mutability of species as each new piece of evidence was added to the puzzle:

During the voyage of the Beagle I had been deeply impressed by discovering in the Pampean formation great fossil animals covered with armour like that on the existing armadillos; secondly, by the manner in which closely allied animals replace one another in proceeding southwards over the Continent; and thirdly, by the South American character of most of the productions of the Galapagos Archipelago, and more especially by the manner in which they differ slightly on each island of the group; none of these islands appearing to be very ancient in a geological sense.

It was evident that such facts as these, as well as many others,

1. See Eiseley 1958:156, 159.

2. See F. Darwin 1887, 1:276; Judd 1909:352-353; Engel 1962:xv; and Barlow 1967:11.

3. See F. Darwin 1888:74, 76; 1903, 1:37-38; 1909:xiv; Barlow 1933:xiii; 1945:262-264; 1963:204-205, 277; 1967:12; Irvine 1955:50; de Beer 1958b:5; 1962:323; Wichler 1961:85-87; Huxdey 1966:3; and Herbert $1968: 44,56$.

4. See T. H. Huxley 1888:xi-xii; Himmelfarb 1959:107-123; Smith 1960:392; Gruber and Gruber 1962:200; Sulloway 1969:99-102; 1979:26-27;1982a:19-20, 22-23; Ghiselin 1969:32-36; Limoges 1970:7-20; and Herbert 1974:249; 1980: 7-12. 
could be explained on the supposition that species gradually become modified; and the subject haunted me. $\quad(1958[1876]: 118-119)^{5}$

In contrast to this statement, Darwin maintained in at least two other accounts of his conversion experience that it had occurred only after his retum from the voyage, not as he was initially observing the various classes of evidence mentioned in his Autobiography. He nevertheless also claimed that while on board the Beagle he had entertained occasional "vague doubts" about the immutability of species."

The last several decades of Darwin scholarship have witnessed a reaction against what Gertrude Himmelfarb (1959:123) once described as the tendency to view Darwin's voyage experiences as the Origin of Species "writ large." Influenced by a more careful scrutiny of Darwin's writings, both published and unpublished, students of Darwin have increasingly come to the conclusion that his conversion to the theory of evolution probably occurred only after his return to England. Yet considerable doubt has continued to exist about the precise timing of Darwin's conversion, owing to the difficulty of dating certain key documents. Moreover, the real story behind the conversion has not been sufficiently understood; and it is this story, rather than the actual timing of the conversion, that serves to distinguish Darwin's genius from the intellectual talent of his scientific contemporaries. In what follows I reconstruct the story of that conversion from the time of Darwin's visit to the Galapagos Archipelago in the fall of 1835 to his decision in July of 1837 to begin the first of a series of notebooks on the transmutation of species.

\section{THE “ORNITHOLOGICAL NOTES”}

Sometime after his visit to the Galapagos Archipelago in September to October of 1835, Darwin made the following famous entry in his Ornithological Notes as he was cataloguing his mockingbird specimens:

I have specimens from four of the larger Islands. . . . The specimens from Chatham and Albermale [sic] Isd appear to be the same; but the other two are different. In each Isld. each kind is exclusively found: habits of all are indistinguishable. When I recollect, the fact

5. See also Darwin 1868, $1: 9-11 ; 1887,2: 23,34 ; 3: 159 ; 1903,1: 118-119$, 367 ; and Haeckel 1876, $1: 134$.

6. See Darwin 1903,1:367; and de Beer 1959:7. 
that from the form of the body, shape of scales \& general size, the Spaniards can at once pronounce, from which Island any Tortoise may have been brought. When I see these Islands in sight of each other, \& possessed of but a scanty stock of animals, tenanted by these birds, but slightly differing in structure $\&$ filling the same place in Nature, I must suspect they are only varieties. The only fact of a similar kind of which I am aware, is the constant asserted difference - between the wolf-like Fox of East \& West Falkland Islds. - If there is the slightest foundation for these remarks the zoology of Archipelagos - will be well worth examining; for such facts [would inserted] undermine the stability of Species. (1963:262)

This passage, which contains Darwin's first explicit intimation of the evolutionary views he was subsequently to promulgate with such revolutionary consequences, has long attracted the interest of Darwin scholars. Unfortunately, both the meaning of the passage (is Darwin endorsing transmutation or is he rejecting it?) and its precise dating have received widely divergent interpretations ever since Lady Nora Barlow first published it almost fifty years ago.

At one historical extreme, complementing Barlow's (1935) original view that the Galapagos experience instituted an immediate "ferment" in Darwin's views about species, many scholars have assumed that the passage in question was written during Darwin's visit to the Galapagos in $1835 .{ }^{7}$ Other scholars, less wedded to the "eureka" concept of scientific discovery, have suggested that the passage was actually written in 1836, sometime during the final leg of the Beagle voyage, and have argued that it betrays only a state of doubt about immutability and not a confident endorsement of unlimited transmutation. ${ }^{B}$

7. Although she did not explicitly date the Ornithological Notes in her 1935 publication, Nora Barlow did describe this document as "contemporary," adding that "the [intellectual] ferment had already begun to work in September 1835" (p. 391). See also Barlow $1945: 246-247$. Her judgment led many subsequent scholars to believe that the notes were written at the time of Darwin's Galapagos visit. See, for example, Lack 1947:9; Irvine 1955:50; and Eiseley 1958:171-172. There is no truth to Julian Huxley's $(1966: 4)$ claim that Darwin elatedly wrote this fam ous passage about the Galapagos mockingbirds in an 1836 letter to Nature. It was Nora Barlow who, a hundred years later, revealed the existence of the passage in her own letter to Nature. That magazine was not founded until 1870 , thirty-five years after Darwin's Galapagos visit.

8. Gruber and Gruber (1962:192) were the first scholars to suggest that the Ornithological Notes was not written contemporaneously with Darwin's visits to 
Still other commentators on this passage have insisted that it dates from early 1837 or even 1838, when Darwin was back in England and was in the process of accepting, or had already accepted, the theory of evolution. ${ }^{9}$

What is certain about these notes is that they were written through out on paper watermarked "J. Whatman 1834." This watermark therefore establishes the earliest possible date of composition for the notes. In addition, the close correspondence of the text with Darwin's voyage diary of zoological observations suggests that the notes are a recopied version, with emendations, of the ornithological portions of that diary. ${ }^{10}$ Fortunately, there now are two independent ways of dating these notes in a much more unequivocable manner than has previously been possible.

During the nearly five years of the Beagle voyage, Darwin's manuscript notes and letters manifested certain characteristic misspellings. Although Darwin was not always consistent over the short run, certain broad patterns are evident in his spelling peculiarities, many of which began to be corrected toward the end of the voyage. This circumstance suggests the possibility of dating the Ornithological Notes by compiling a comprehensive table of Darwin's spelling habits in the period 1832 to 1837 .

Five words in particular prove relevant: occasion, occasional, and occasionally, which Darwin frequently spelled with double $s$ 's; coral, sometimes spelled with two l's; and Pacific, sometimes spelled with a $k$ on the end. If the variant spellings are collated by years of the voyage, using the more than three thousand manuscript pages of Beagle scientific

the recorded localities, but rather during the last few months of the Beagle voyage, when he may have been recopying sections of his zoological notes. Howard Gruber, who still adheres to this opinion (1974:101), admits that it is only an educated guess based on the format of the notes and the likely nature of Darwin's activities at the time. Although Barlow (1963:204) seems to have accepted this later dating of the notes, she has held fast to her earlier view that "the shock of seeing species differentiation through isolation actually in progress in the different islands of the Galapagos Archipelago" caused Darwin's conversion at that time (p. 277). See also de Beer 1962:323; 1963:82.

9. See, for example, Himmelfarb 1959:463-464n25; Smith 1960:400; Engel 1962:xix; Limoges 1970:13-14; and Grinnell 1974:262n9. Herbert (1974:239240), who allows for a possible voyage dating of these notes, also argues that they could have been drafted as late as January 1837 .

10. DAR 31.1 and 31.2. All DAR numbers refer to the Darwin manuscripts at Cambridge University Library. 
notes and letters, a fairly coherent pattern emerges(Table 1). ${ }^{11}$ Occasion and its various derivatives were increasingly displaced by the double-s

Table 1. Variations in Darwin's voyage spellings, 1832 to $1836(\mathrm{~N}=302)$. $^{\mathrm{a}}$

\begin{tabular}{|c|c|c|c|}
\hline \multirow[b]{2}{*}{ Year } & \multicolumn{3}{|c|}{ Word and variants } \\
\hline & Occasion & Coral & Pacific \\
\hline \multirow{2}{*}{1832} & Occasion (8) & Coral (2) & \multirow{2}{*}{ Pacific (2) } \\
\hline & Occassion (6) & Corall (5) & \\
\hline \multirow{2}{*}{1833} & Occasion (11) & $\operatorname{Coral}(1)^{\mathrm{e}}$ & \multirow{3}{*}{ (6) } \\
\hline & Occassion (10) & Corall (1) & \\
\hline \multirow{4}{*}{1834} & Occasion (3) & 1 & \\
\hline & Occassion $(22)^{b}$ & 1 & \multirow{3}{*}{$\begin{array}{l}\text { Pacific (11) } \\
\text { Pacifick (1) }\end{array}$} \\
\hline & | & 1 & \\
\hline & i & 1 & \\
\hline \multirow{3}{*}{1835} & I & & Pacific (4) \\
\hline & 1 & Corall $(21)^{\mathbf{f}}$ & \multirow{7}{*}{$\begin{array}{c}\text { Pacifick (15) } \\
\vdots \\
\text { Pacifick }(8)^{\mathrm{j}} \\
\text { Pacific }(2)^{\mathrm{k}}\end{array}$} \\
\hline & 1 & Coral $(60)^{g}$ & \\
\hline \multirow{5}{*}{1836} & i & 1 & \\
\hline & 1 & & \\
\hline & $\downarrow$ & & \\
\hline & Occassion $(22)^{\mathrm{c}}$ & & \\
\hline & Occasion (4) ${ }^{d}$ & Coral (45) & \\
\hline
\end{tabular}

a. Solid lines indicate continuous periods of correct spellings; broken lines indicate continuous periods of incorrect spellings. Figures in parentheses show numbers of times the particular spelling occurred.

11. To this end, I have systematically examined Darwin's unpublished diary of observations on geology and zoology (DAR 31-38); his personal voyage diary, letters, and pocket notebooks at Down House, Downe, Kent (Darwin 1933, 1945); his voyage letters to John Stevens Henslow at the Royal Botanic Gardens, Kew (Darwin 1967); his voyage letters to William Darwin Fox at Christ's College Library, Cambridge; and other relevant voyage documents at Cambridge University Library. 
b. Occassion became the exclusive spelling in March 1834 (DAR 32.2: MS pp. 137, 147).

c. Occassion was last used between August 12 and mid-September 1836, probably toward the end of this interval (DAR 32.1 [series 2]: MS p. 3; Red Notebook, MS p. 93e; see also note 74).

d. Occasion was first used again sometime after August 6, 1836 (probably during the following two weeks), and was used again on September 20, ca. September 25, and on October 24, 1836 (DAR 32.1 [series 2]: MS p. 7; Darwin 1933: MS p. 759; Red Notebook, MS p. 107; and de Beer 1958a:111).

e. Coral was last used in July 1833 (Darwin 1967:76).

f. Corall was last used in December 1835 (Darwin 1962 [1835]).

g. Coral was first used again on November 24, 1835 (Darwin 1933: MS p. 647).

h. Pacifick was first used in September 1834 (DAR 31.3: MS p. 278).

i. Pacifick became the exclusive spelling in October 1835 (DAR 37.2: MS pp. 791, 792).

j. Pacifick was last used sometime between August 12 and mid-September 1836, probably toward the end of this interval (Red Notebook, MS p. 97e; see also note 74).

k. Pacific was first used again on September 25, 1836 (Darwin 1933: MS p. 769).

spelling during the first two years of the voyage. By March of 1834 the double-s form had become the exclusive spelling, which prevailed for the next twenty-nine months. Then, sometime between August 12 and mid-September 1836, the double $s$ was dropped from occasion and never reappeared. Coral and corall also alternated for the first two years of the voyage. Over the next twenty-three months only corall was used. This spelling finally began to be corrected in late November and early December of 1835 , as Darwin was writing an essay on coral islands. ${ }^{12}$ Thereafter the correct spelling prevailed. Pacific, used exclusively until September 1834, was completely displaced by Pacifick after October 1835. This spelling remained the exclusive one until September 25, 1836 , when the correct spelling reappeared to stay. ${ }^{13}$

12. See "Coral Islands" in DAR 41 . This essay has been published by $D . R$. Stoddart (see Darwin 1962[1835]).

13. Table 1 is complete in its survey of manuscript sources through 1836 . I have also checked all available postvoyage manuscripts datable to 1837 , and although the number of instances of these three key words (and their derivatives) is not great, they are in all cases spelled conectly. Darwin also misspelled six other less frequently used words during the Beagle voyage: neighbourhead, thoroughily. yatch, broard, maneuvre, and Portugeese. None of these spellings were corrected during the voyage itself. See further Barlow 1933:xix. Darwin purchased a dictionary at the Cape of Good Hope sometime between May 31 and June 18, 


\section{FRANK J. SULLOWAY}

If one regards these variations in spelling in the same way that a geologist views the characteristic fossil remains present in a large series of geological strata, they may be used, like fossils, as a sort of temporal guide against which any sufficiently lengthy document of unknown date may be compared. The Ornithological Notes is characterized throughout by the presence of the double $s$ in occassion (thirteen instances) and by the spellings Pacifick (three instances) and coral (one instance). ${ }^{14}$ From Table 1 it is evident that any document with these various spellings could not have been composed earlier than the end of November 1835 or later than mid-September 1836, a ten-month span in all. The notes were clearly drafted, then, during the last year of the voyage. The famous passage about the Galapagos mockingbirds had to have been written between five weeks and eleven months after Darwin had left the Galapagos Archipelago.

A second method of dating the Ornithological Notes allows us to pinpoint the time of composition in a more precise manner, by comparing these notes with eleven other voyage catalogues of almost identical format. Like the Ornithological Notes, the eleven catalogues were all written on paper watermarked "J. Whatman 1834." And like the Ornithological Notes, the other catalogues list the specimens that Darwin collected on the voyage, each catalogue being devoted to a separate branch of natural history. ${ }^{15}$ All twelve catalogues were

1836 (Darwin $1945: 252$ ). His subsequent correction of several previously misspelled words was probably prompted by this acquisition.

14. Nora Barlow $(1963: 212,231,247)$, in spite of her sensitivity to (and attempts to preserve) Darwin's spelling peculiarities in the Ornithological Notes, in three instances omitted the double $s$ of occassion and its derivatives. I have drawn upon the unpublished manuscript for all of these misspellings (see DAR 29.2). In my tabulations, all of Darwin's rectifications of spellings have been ignored as long as the incorrect spelling was clearly penned first and corrected only at a later date. There are several such instances in the Ornithological Notes $(1963: 211,222,228,242)$. These notes also include one example of occasionally spelled correctly $(1963: 241)$. I have not counted this instance, since the word appears in a note added to the text at a later date, apparently after the voyage, and is in the same color ink as was used to correct earlier misspellings of the word. Throughout the Beagle voyage Darwin also consistently misspelled the common name of a species of South American mockingbird (Calandria, misspelled as Callandra). There are eight such instances in the Ornithological Notes, one of which was corrected after the voyage. See note 65 for the dating of this spelling change.

15. See DAR 29.1: "Animals"; "Fish in Spirits of Wine"; "Insecta"; and "Shells in Spirits of Wine"; and DAR 29.3 : "Shells"; "Insects in Spirits of Wine"; 
evidently drawn up late in the voyage for the specialists who Darwin expected would name and describe his collections after his retum to England. Several of the catalogues bear witness to subsequent use in this manner. Two of them, kept by Richard Owen, are stamped as having come from his literary estate, where they were discovered after Owen's death. Another, the reptiles catalogue used by Thomas Bell, is now at the British Museum (Natural History), along with Bell's manuscript notes on Darwin's collection. A fourth catalogue, on fish, is annotated in the hand of Leonard Jenyns. ${ }^{16}$ Unfortunately, none of the catalogues are dated. Nor, except for the Ormithological Notes, can any of them be dated by their spellings, since they either are in the hand of Darwin's servant (with correct spellings) or do not contain sufficient instances of the key spellings to permit precise dating.

What is noteworthy about these catalogues, besides their uniform appearance, is that most of them appear to have been composed before the Beagle had finished its itinerary. The lists proceed uniformly until reaching specimen numbers corresponding generally to the period between April 12 and August 6,1836. ${ }^{17}$ The "Animals" catalogue, for instance, includes all of the specimens collected up to and including the Beagle's visit to Mauritius, from which the ship departed on May 9, 1836. At this point the catalogue continues with a series of general essays on some of the more noteworthy animals that Darwin had collected in South America. At the end of the series of essays are brief listings of the animals that Darwin collected after leaving Mauritius, namely, two rats and two mice from Ascension Island. It seems clear that the bulk of the "Animals" notes were drafted sometime between May 9, when the Beagle left Mauritius, and July 19, when the Beagle arrived at Ascension. Similarly, Darwin's ornithological catalogue

\footnotetext{
"Mammalia in Spirits of Wine"; and "Birds in Spirits of Wine." See also the British Museum (Natural History), Zoology Library: "Reptiles in Spirits of Wine";", Entomological Library: "Insects"; and Herbarium, Botany School, Cambridge University: "Plants."

16. For the identification of Jenyns's handwriting see Herbert (1974:238n62), who nevertheless has confused the reptiles catalogue with the fish catalogue in this connection.

17. These two dates are based on a comparison of the twelve lists with Darwin's six master catalogues for specimens, now at Down House, Downe, Kent. See "Catalogue for Animals in Spirits of Wine ... Nos: 1 to 660"; "Catalogue for Specimens in Spirits of Wine. - no 661-1346"; "Catalogue for Specimens in Spirits of Wine [ $n^{\circ}$ 1347-1529]"; "Printed Numbers ... Nor 1-1425"; "Printed Numbers n.' 1426 . . 3342"; and "Printed Numbers 3345[-3907]."
} 


\section{FRANK J. SULLOWAY}

includes all of the birds collected up to and including his visit to Keeling Island, from which the Beagle departed on April 12 of the same year. A series of general essays on various birds already recorded then follows, but the list fails to include any of the birds Darwin later collected at Ascension Island or the Cape Verde Islands. ${ }^{18}$ Hence the catalogue for birds, like that for animals, appears to have been drawn up prior to Darwin's arrival at Ascension Island (on July 19) and was apparently begun sometime after the Beagle left Keeling Island on April 12.

Similar analyses of all the catalogues yield the following pattern of dates, within which the notes as a whole were evidently begun and completed. From Table 2 it may be seen that the two latest catalogues

Table 2. The composition dates of Darwin's "J. Whatman 1834" specimen catalogues.

\begin{tabular}{|c|c|c|}
\hline Catalogue & $\begin{array}{l}\text { Probably begun and } \\
\text { definitely completed } \\
\text { sometime after - }\end{array}$ & $\begin{array}{l}\text { Definitely completed } \\
\text { sometime before - }\end{array}$ \\
\hline "Insecta" a & - & - \\
\hline $\begin{array}{l}\text { "Insects in Spirits } \\
\text { of Wine" a }\end{array}$ & - & - \\
\hline $\begin{array}{l}\text { "Birds in Spirits } \\
\text { of Wine" }\end{array}$ & - & - \\
\hline $\begin{array}{l}\text { "Mammalia in Spirits } \\
\text { of Wine" c }\end{array}$ & - & $\begin{array}{l}\text { August } 12,1836 \\
\text { (arrival at } \\
\text { Pernambuco, Brazil) }\end{array}$ \\
\hline "Plants"d & $\begin{array}{l}\text { April 12, } 1836 \\
\text { (departure from } \\
\text { Keeling Island) }\end{array}$ & - \\
\hline "Ornithology" & $\begin{array}{l}\text { April 12, } 1836 \\
\text { (departure from } \\
\text { Keeling Island) }\end{array}$ & $\begin{array}{l}\text { July } 19,1836 \\
\text { (arrival at } \\
\text { Ascension Island) }\end{array}$ \\
\hline
\end{tabular}

18. Nevertheless, to an essay about the frigate bird Darwin added a subsequent footnote on the back of a sheet describing what he had been told at Ascension Island about the feeding habits of this bird (1963:267). Darwin's failure to complete this catalogue by adding specimens later collected at Ascension Island and the Cape Verde Islands was apparently an oversight. 
Darwin's Conversion

Table 2 (continued)

\begin{tabular}{|c|c|c|}
\hline Catalogue & $\begin{array}{l}\text { Probably begun and } \\
\text { definitely completed } \\
\text { sometime after - }\end{array}$ & $\begin{array}{l}\text { Definitely completed } \\
\text { sometime before - }\end{array}$ \\
\hline $\begin{array}{l}\text { "Shells in Spirits } \\
\text { of Wine" }\end{array}$ & $\begin{array}{l}\text { April 12,1836 } \\
\text { (departure from } \\
\text { Keeling Island) }\end{array}$ & $\begin{array}{l}\text { August } 12,1836 \\
\text { (arrival at } \\
\text { Pernambuco, Brazil) }\end{array}$ \\
\hline "Animals" & $\begin{array}{l}\text { May 9, } 1836 \\
\text { (departure from } \\
\text { Mauritius) }\end{array}$ & $\begin{array}{l}\text { July } 19,1836 \\
\text { (arrival at } \\
\text { Ascension Island) }\end{array}$ \\
\hline $\begin{array}{l}\text { "Fish in Spirits } \\
\text { of Wine"e }\end{array}$ & $\begin{array}{l}\text { May 9, } 1836 \\
\text { (departure from } \\
\text { Mauritius) }\end{array}$ & - \\
\hline $\begin{array}{l}\text { "Reptiles in Spirits } \\
\text { of Wine"f }\end{array}$ & $\begin{array}{l}\text { June } 18,1836 \\
\text { (departure from the } \\
\text { Cape of Good Hope) }\end{array}$ & - \\
\hline "Shells" & $\begin{array}{l}\text { July } 14,1836 \\
\text { (departure from } \\
\text { St. Helena) }\end{array}$ & $\begin{array}{l}\text { August } 12,1836 \\
\text { (arrival at } \\
\text { Pernambuco, Brazil) }\end{array}$ \\
\hline "Insects" & $\begin{array}{l}\text { August 6, } 1836 \\
\text { (departure from } \\
\text { Bahia, Brazil) }\end{array}$ & - \\
\hline
\end{tabular}

a. Catalogue discontinued soon after having been begun.

b. No birds were preserved in spirits of wine after October 1835 .

c. No mammals were preserved in spirits of wine between March 1835 and August 1836.

d. No plants, except no. 1465 in spirits of wine (collected in St. Jago, Cape Verde Islands, between August 31 and September 5, 1836), were collected after April 12, 1836. As far as is known, Darwin did not prepare a separate catalogue for plants in spirits of wine. The fact that he failed to include the St. Jago specimen as the last item in his "Plants" catalogue suggests that this catalogue was already completed before the Beagle reached the Cape Verde Islands.

e. No fish were collected after May 9, 1836 .

f. No reptiles were collected after June 18,1836 . 
(the "Shells" and the "Insects") were begun after July 14 and August 6, 1836 , respectively. ${ }^{19}$ On the other hand, at least two catalogues (the Ornithological Notes and the "Animals") were definitely completed by July 19, 1836. Three more ("Mammalia in Spirits of Wine," "Shells in Spirits of Wine," and "Shells") were certainly completed that year before August 12, when the Beagle reached Pernambuco, Brazil. It is these seven catalogues, together with the thirty-five-day interval between July 14 and August 12, that enable us to date all the others. The reason that all the catalogues do not yield roughly these same two dates of commencement and completion is simply that Darwin did not collect specimens in every branch of natural history from every locality he visited. Hence all the catalogues in Table 2 that suggest earlier or later dates of composition appear to do so only on the basis of these collecting differences. Had Darwin collected specimens appropriate to each catalogue at every locality, it is highly likely that most of the catalogues would bear witness to their composition between mid-July and early August 1836. All specimens collected after these dates would doubtless have been added to the ends of the catalogues, as they clearly were to at least five of the ten (all those in Table 2 that $I$ have indicated as being completed before August 12,1836).

In summary, eight of the twelve catalogues were unequivocally

19. I have regarded catalogues as being "probably begun and definitely completed" after the dates indicated in Table 2 on the basis of the following criteria. Many of the catalogues are written in the hand of Darwin's servant, Syms Covington, except for specimens at the end that were clearly added later by Darwin. These catalogues were therefore essentially finished, except for the later additions, no earlier than the date the Beagle departed from the locality of Covington's last recorded specimen. Since the average catalogue length is less than twenty pages (perhaps a day's worth of recopying), their earliest possible completion dates may be taken as roughly identical with the earliest possible dates on which they were begun.

The earliest dates on which Darwin could have begun the catalogues written largely in his own hand were derived by an analogous method. Toward the end of these catalogues there often occur general essays and a few additional specimens corresponding to localities that Darwin visited only after drafting the essays. Such catalogues were judged as being "apparently begun and definitely completed," except for the few specimens added later, no earlier than the Beagle's date of departure from the locality of the last regularly recorded specimen. Catalogues were judged as being completed before the dates indicated in Table 2, given the localities of the specimens that were clearly added to the catalogue later, or, in the case of the Ornithological Notes, given Darwin's failure to include certain specimens that were evidently not yet collected at the time he was writing the general essays. See also note 18 . 
composed after April 12, 1836, and three of these eight were composed after June 18 , the earliest date by which the recopying actually appears to have gotten underway. In general agreement with this interpretation, two catalogues, including the Ornithological Notes, were completed by July 19; three more were finished by August 12, when the last of the recopying work was probably concluded. Thus all twelve catalogues were evidently composed sometime during a two-month period (at most), from mid-June to mid-August $1836 .{ }^{20}$ From the amount of material that Darwin and his servant, Syms Covington, had to recopy in these catalogues (219 pages in all), it is not impossible that all the catalogues were drawn up during the thirty-day period from July 14 to August 12, the briefest interval that is in fact consistent with the composition of all twelve. Just as plausibly, however, the catalogues were composed sequentially during four separate intervals, encompassing fifty-six days, while the Beagle was at sea: June 18 to July 7, during the voyage from the Cape of Good Hope to St. Helena; July 14 to 17, while sailing to Ascension Island; July 23 to August 1, during the voyage to Bahia, Brazil; and August 6 to 12, on the way to Pernambuco, Brazil. In any event, there can be little question that Darwin's catalogue for ornithological specimens, completed by July 19, 1836, was drafted sometime during the previous thirty-one days, while the Beagle was sailing to St. Helena and Ascension islands from the Cape of Good Hope.

\section{DARWIN'S GALAPAGOS EXPERIENCE}

More important perhaps than the dating of Darwin's Ornithological Notes is the proper interpretation of that document's famous passage about the Galapagos mockingbirds. This passage should certainly not be read, as it sometimes has been, as the statement of a confirmed believer in the theory of transmutation. Darwin apparently drew face to face with that possibility, only to reject it on the grounds that the mockingbirds were probably "only varieties." Several recent scholars have endorsed a similar interpretation of this passage. ${ }^{21}$ What has not been

20. Since Darwin never used paper watermarked "J. Whatman 1834" prior to drafting these twelve specimen catalogues, it is reasonable to suppose that he purchased this paper at the Cape of Good Hope (a British port) sometime between May 31 and June 18,1836 . He would have waited to commence recopying until he had put to sea and had updated both his scientific notes and his personal journal.

21. See Ghiselin 1969:34-35; Herbert 1974:236-240; and Kottler 1978:281. 
properly understood are the various aspects of Darwin's Galapagos visit that led him briefly to entertain, and then to reject, an evolutionary interpretation.

The reported differences among the various island populations of the Galapagos tortoise are particularly relevant. In his Joumal of Researches Darwin later commented that the possibility that the numerous islands of the Galapagos group might be tenanted by slightly different forms was first brought to his attention by Nicholas $O$. Lawson, vice-governor of the islands. Lawson, whom Darwin met on Charles Island (the second of the four islands Darwin visited), informed him that "the tortoises differed from the different islands, and that he could with certainty tell from which island any one was brought" $(1845: 394)$. This conversation took place sometime between September 25 and 27, 1835, during the second of Darwin's five weeks in the archipelago. ${ }^{22}$ "I did not for some time," Darwin asserted, "pay sufficient attention to this statement, and I had already partially mingled together the collections from two of the islands. I never dreamed that islands, about fifty or sixty miles apart, and most of them in sight of each other, formed of precisely the same rocks, placed under a quite similar climate, rising to a nearly equal height, would have been differently tenanted.... [B] ut I ought, perhaps, to be thankful that I obtained sufficient materials to establish this most remarkable fact in the distribution of organic beings" (1845:394). What Darwin did not go on to relate in his Journal account of this episode are the various reasons that caused him initially to disregard the vice-governor's comments.

The key to Darwin's oversight lies in the specific name - Testudo indicus - by which the Galapagos tortoise was known at the time. In the 1830s two different species of giant land tortoise, one from the Aldabra Islands in the Indian Ocean and the other from the Galapagos, had been confused under this name. This error in systematics had in turn encouraged the mistaken belief that the Galapagos form of giant tortoise was not actually native to those islands but had been transported there by buccaneers and, earlier, by the oceangoing peoples of the Pacific islands. Captain Robert FitzRoy reiterated this view in his own published account of the Beagle voyage. There he emphasized that virtually no animal was more suited for extensive ocean transport, since the giant land tortoise was easily caught and good to eat, and required

22. Lawson boarded the Beagle on September 25 and then escorted a group, including Darwin and FitzRoy, to the settlement in the highlands (FitzRoy $1839: 490$ ). Darwin spent four days on Charles Island, the last being September 27. See also Darwin's Diary (1933:336). 
little food or water for long periods (1839:505). FitzRoy also cited the views of the buccaneer William Dampier, who claimed to have seen another variety of this species at Madagascar and elsewhere in the Indian Ocean (1729:202). Like Dampier, FitzRoy had no doubt that the Galapagos form of tortoise was a mere variety of this other race, slightly altered by removal to its new environment

It was this widespread confusion regarding the original habitat of the Galapagos tortoise that apparently caused Darwin, like FitzRoy, to dismiss the reported island differences as a phenomenon readily explained by the changes in form that customarily accompany an animal's introduction into a dissimilar country. ${ }^{23}$ Since Testudo indicus was already known to be a single species, Darwin seems to have concluded that the differences found on the various islands of the Galapagos were merely varietal peculiarities somehow dependent upon the harsh and by no means identical environmental conditions of each island. Prior to realizing the degree to which the separate islands of the Galapagos were tenanted by distinct species, Darwin had already learned that the islands varied considerably in size, height, terrain, availability of fresh water, and even degree of vegetation. Moreover, he knew that such differences were occasionally associated with other local variations of an apparently subspecific nature. In his voyage Diary, for example, he recorded that "those [plants] of the same species" attained a much greater size on James Island than elsewhere in the archipelago $(1933: 340){ }^{24}$ Similarly, he observed in his zoology notes that the marine iguanas grew to their largest size on Albemarle Island, the main landmass of the Galapagos group. ${ }^{25}$ In the light of these analogous observations, none of which seems to have troubled Darwin, what he

23. Darwin was also misinformed at this time about the geographic distribution of the endemic marine iguana (Amblyrhynchus cristatus), which had previously been described from a stuffed specimen sent from Mexico and erroneously thought to have come from the nearby shores of the Pacific. Hence the endernic status of the two most striking reptiles in the Galapagos was not known to Darwin at the time of his visit. See DAR 31.2: MS pp. 333, 339.

24. In making this botanic observation, Darwin was probably confusing subspecific with specific differences among representative species on the various islands. In his Journal he later acknowledged in this connection: "From my ignorance in botany, I collected more blindly in this department of natural history than in any other; so that certainly it was not intentionally that I brought the different species from different islands. If, indeed, $I$ at all noticed their resemblance, I probably collected second and third species as duplicate specimens of the first" (1839:629).

25. See DAR 31.2: MS p. 333. 
was told about the tortoises might have seemed curious to him, but nothing more. For even under the theory of creation, species were believed to be capable of considerable local variation owing to environmental influences.

Darwin's attitude toward the reported differences among the tortoises was reinforced by one other circumstance that has gone unrecognized in connection with his visit to the Galapagos. The first island Darwin visited, and the place where he saw his first tortoise, was Chatham Island (Fig. 1). From there the Beagle proceeded to Charles

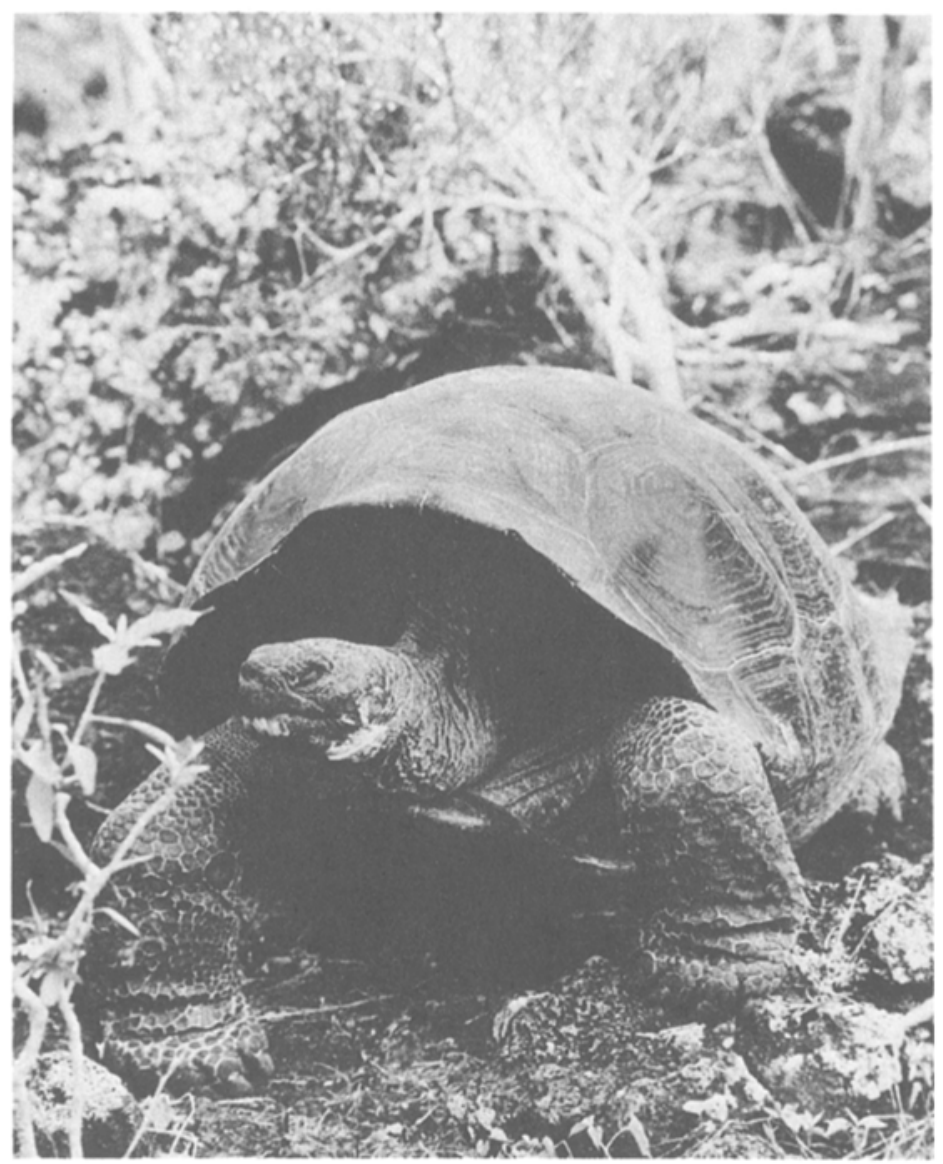

Fig. 1. The Chatham Island tortoise (Geochelone elephantopus chathamensis), a relatively dome-shaped form. Photographed by the author in the interior of northeastern Chatham Island. 
Island, where the vice-governor was residing. The Charles Island tortoise, like the nearby Hood Island variety, has its shell tumed up in front like a Spanish saddle. This is an adaptation found on the smaller and drier islands, allowing the tortoise to stretch its neck much higher in search of food (Fig. 2). At the time of the Beagle's visit to Charles Island, this distinctive saddleback tortoise was nearly extinct, and apparently no live ones were seen by Darwin or FitzRoy. Nevertheless, Darwin did

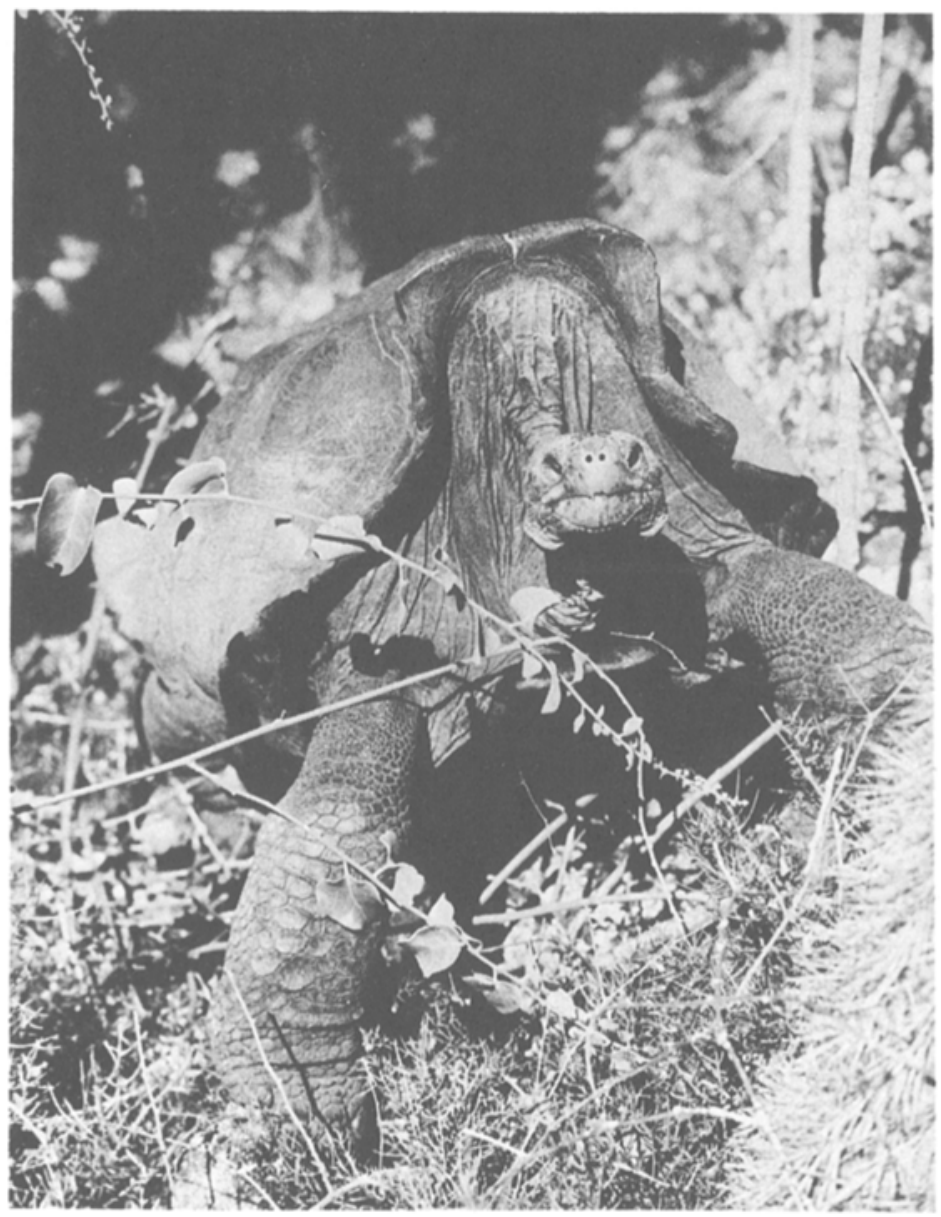

Fig. 2. The Hood Island tortoise (Geochelone elephantopus hoodensis), an extreme saddleback form similar to the nowextinct Charles Island race ( $G$. elephantopus galapagoensis). Photographed by the author at the Charles Darwin Research Station, Isla Santa Cruz. 
have at least one opportunity to observe the unusual Charles Island form of tortoise shell. Carapaces were readily visible at the settlement, where they were being used as flowerpots (FitzRoy 1839:492). Unfortunately, neither Darwin nor FitzRoy thought it important to procure a specimen for scientific purposes, or even to record the form of the shell as compared with the Chatham Island form. ${ }^{26}$

From Charles Island Darwin proceeded to Albemarle Island, where he spent only part of a day on shore (October 1) and did not see any tortoises. Then on October 8, Darwin, his servant, and three other men were left on James Island for nine days in order to collect specimens from this large and central location. In the James Island highlands Darwin saw many tortoises. As luck would have it, the James Island tortoise is fairly similar to the Chatham Island race, the only other form that Darwin had personally seen (Fig. 3). Both have a carapace that is relatively dome-shaped, the other of the two morphological extremes found in the archipelago. Darwin, noticing no real difference based on his memories of the Chatham Island tortoise, probably concluded that whatever distinguishing features there were could not be all that pronounced. ${ }^{27}$ In fact specialists in herpetology can by no means tell

26. Within about ten years of the Beagle's visit the Charles Island race of tortoise was extinct. Zoologists had to wait nearly a century before remains of this form were discovered in a lava cave (Broom 1929).

27. It is interesting to compare Darwin's contemporaneous account of Lawson's remarks in his zoological diary with his account published after he had become an evolutionist and had finally grasped the full importance of this case. The pencil additions to the following passage in the zoology notes were undoubtedly made as Darwin was preparing his Joumal for publication in the spring of 1837: "It is said that slight variations in the form of the shell are constant according to the Island which they inhabit - also the average largest size appears equally to vary [according to the locality inserted in pencil]. Mr. Lawson states he can on seeing a Tortoise pronounce [with certainty inserted in pencil] from which Island it has been brought" (DAR 31.2: MS p. 328). In the Journal Darwin gave even more emphasis to these claims, introducing his discussion with the statement, "It was confidently asserted, that the tortoises coming from different islands in the archipelago were slightly different in form," and concluding his discussion with the sentence, "Mr. Lawson maintained that he could at once tell ..." (1839:465; italics added).

Thus Darwin's recollections about his conversation with Lawson, in which Lawson's testimony became increasingly emphatic, were apparently influenced by his theoretical transformation during the next two years. This process may have begun as early as nine months after Darwin's departure from the Galapagos, when he was rewriting his omithological observations and first raised the question of whether the "stability of Species" was challenged by such evidence. The phrase 


\section{Darwin's Conversion}

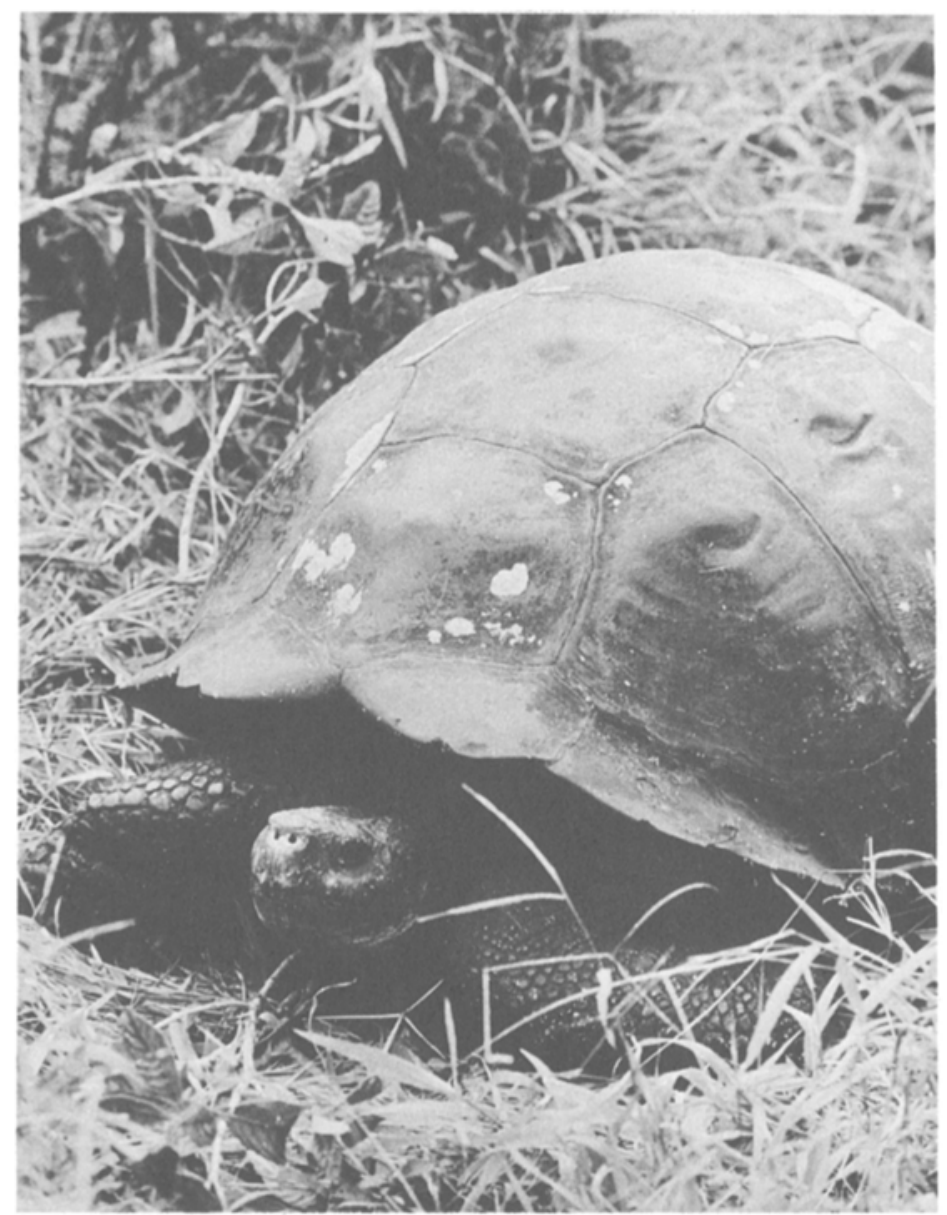

Fig. 3. The James Island tortoise (Geochelone elephantopus darwini), a domeshaped form. Photographed by the author in the highlands on James Island.

\footnotetext{
"at once" appears there for the first time in reference to the tortoises, although the ability to identify the tortoises by island is there attributed to "the Spaniards" and not to Lawson (1963[1836]:262). Darwin may have later discussed this subject on James Island with the Spaniards sent there by Law son to hunt tortoises and to salt the meat. If this is the case, then Darwin subsequently compressed two separate discussions of this subject into one, apparently transferring the words "at once" to Lawson's account.
} 
at a glance what island any Galapagos tortoise is from, and the vicegovernor's claim was something of an exaggeration. ${ }^{2 B}$

After his departure from James Island to sail for Tahiti, Darwin had one last opportunity to follow up the vice-governor's claims about the tortoises. FitzRoy, during Darwin's stay on James Island, had returned to Chatham Island for water. There he had also taken on thirty large tortoises, to be stored in the ship's hold as a supply of fresh meat during the Beagle's cruise across the Pacific $(1839: 498)$. But Darwin and the other crew members gradually ate their way through the evidence that eventually, in the form of hearsay, was to revolutionize the biological sciences. Regrettably, not one of the thirty Chatham Island carapaces reached England, having all been thrown overboard with the other inedible remains.

Two small tortoises, evidently kept as pets by Darwin and his servant, did survive the Beagle voyage. When Darwin, back in England, finally realized the necessity for having an expert compare the various forms of tortoise, these, together with two specimens that FitzRoy had procured for the British Museum, were his only sources of evidence. ${ }^{29}$

28. Just how exaggerated the vice-governor's claim really was may be gathered from the attempts of present-day herpetologists to identify various Galapagos tortoises of uncertain origin. During the last decade, zoos all over the world have retumed numerous Galapagos tortoises to the Charles Darwin Research Station (Isla Santa Cruz) to assist in the tortoise conservation and breeding program. Of the fifty-odd tortoises thus far repatriated, only one (a male from Hood Island) has been identified by locality. The remainder, separated by sex so they cannot interbreed, are kept in pens labeled "Varias Islas." Although the varieties of Galapagos tortoise can indeed be separated into two extremes (dome-shaped and saddleback forms), it is at present virtually impossible to distinguish forms that are relatively similar. Moreover, some forms of Galapagos tortoise exhibit considerable polymorphism. Chatham Island, for example, is inhabited by a dome-shaped form (in the highlands) as well as by a form with a somewhat more intermediate carapace (from the lower, northeastern part of the island). Volcan Wolf on Albemarle Island has, for unknown reasons, a continuous range of variation between domeshaped and extreme saddleback forms. So subtle are the differences between the tortoises from some of the islands that film makers, in attempting to document the historical importance of this point in Darwin's thinking, have been able to ignore it in photographic practice. For example, in the BBC's seven-part dramatization of the life of Darwin, footage of at least two different races of Galapagos tortoise (the Isla Santa Cruz form and that from Volcán Alcedo on Albemarle Island) were interspliced at a point in the film where Darwin was supposed to be observing just one form. See Ralling 1978.

29. See DAR 29.3:40, MS p. 7v; and "Zoological Accessions 1837," p. 1, British Museum (Natural History), Mammals Library, London. FitzRoy's two tortoises were from Hood Island; Darwin's and Covington's were from James and Charles islands, respectively. 
Although the four tortoises were from three different islands, the prominent variations in the carapace emerge only after several decades of growth. Darwin's specimens were unfortunately much too young to allow any meaningful scientific comparison of the various forms (1839:465).

It was also upon his retum to England that Darwin was told by Thomas Bell and other herpetologists that in their opinion the Galapagos tortoise was almost certainly native to that archipelago. In his Journal Darwin therefore argued that the Galapagos tortoise had probably been transported from there to the islands of the Indian Ocean, rather than vice versa (1839:465-466). Subsequently, the two tortoise forms were recognized as specifically distinct and hence of independent origins. In the second edition of his Journal Darwin at last was able to replace the inappropriate name Testudo indicus with $T$. nigra, thereby ending the taxonomic confusion between the two species (1845:382).

Similarly, the real evidence concerning the distinct island forms of the Galapagos tortoise emerged only after the voyage. Early in 1838 Darwin encountered a French herpetologist, Gabriel Bibron, who insisted that he had seen at least two species of full-grown tortoises from the Galapagos Islands. ${ }^{30}$ This information came just in time to be included in the Addenda to Darwin's Journal (1839:628). It was not, however, until the second edition $(1845: 394)$ that Darwin was able to describe the different dome-shaped and saddleback carapaces, based on Captain David Porter's informative report thirty years earlier (1815, 1:215). So it took Darwin fully a decade to resupply the scientific evidence that he had allowed to slip through his fingers when he visited the Galapagos Archipelago in 1835 .

Analogous to the legendary roles assigned to the Galapagos tortoises and mockingbirds, it has been widely claimed that Darwin's finches, a

30. Bibron spoke on February 28,1838 , at the Zoological Society, where he was granted permission to examine the society's collection of reptiles. Darwin, in a passage that has an approximate dating of late February or early March 1838 , mentioned a conversation with Bibron at the society in his second transmutation notebook (de Beer 1960-1961: C 54). See also "Zoological Society Minutes of Council," $5: 277$. In an old, unfilled Edinburgh notebook that Darwin was also using at this time, he elatedly wrote: "The French [Jessold? deleted, Bibron inserted] coworker of Dumeril who is writing with Dumeril says that two species of Tortoise come from the Galapagos!!!" See DAR 118:[17]. Contrary to Bibron's opinion, the Galapagos tortoise is now considered to be a single species (Geochelone elephantopus) composed of eleven living and four extinct subspecies (Thornton 1971:115). 
peculiar group of Galapagos birds, played a key role in converting Darwin to the theory of evolution. ${ }^{31}$ According to David Lack (1947: 23), Darwin began to separate his finches by island shortly after hearing the vice-governor's testimony on Charles Island that the tortoises from the different islands could be differentiated. Lack based his assertion on certain of Darwin's own statements about his collections, as well as on the fact that many of Darwin's type specimens at the British Museum are labeled as coming from James Island, the last of the four islands Darwin visited. In his Joumal of Researches Darwin later sought to compare his collection of finches from that island with those specimens procured on either Chatham or Charles Island, and he was thus able to suggest that some of the species might be geographic representatives of one another $(1845: 395)$.

Contrary to the impression he may have given, Darwin derived virtually all of this locality information for the Galapagos finches by borrowing, after his return to England, the carefully labeled collections of other Beagle shipmates. It was primarily these locality data that Darwin, who also made some educated guesses about his own specimens' localities, later published in the Zoology of the Voyage of H.M.S. Beagle (1841:100-106) and in his Journal of Researches $(1845: 395)$. Unfortunately, in the process of trying to reconstruct the island localities of his own specimens, Darwin made a number of mistakes. He also erred in his attempts to correlate the results of the four different Beagle collections. Further inaccuracies are associated with his published claim, based on only fragmentary evidence, that

31. Many authorities have stressed the role of Darwin's finches in bringing about his conversion and have usually dated that conversion to Darwin's visit to the Galapagos Islands. See, for example, J. Huxley 1954:6; 1966:9; Eibl-Eibesfeldt 1961:18; Peterson 1963:11-12; Darling and Darling 1963:34; Moorehead 1969:202; Grzimek 1973:359; Olney 1976:135; Dobzhansky et al. 1977:12; and Jensen et al. 1979:486. The following commentators, who do not date Darwin's conversion or who place it later than the actual Galapagos visit, nonetheless emphasize the critical role of the finches: Swarth 1931:10; Wynne-Edwards 1947:687; Mayr 1947:217; Eiseley 1958:172-173; de Beer 1963:132; Moody 1970:303; Leigh 1971:136; Thornton 1971:12, 161-162; Grinnell 1974:259, 263; Dorst 1974, 2:552; Silverstein 1974:505; Thompson 1975:10; Kimball 1978:587; Freeman 1978:147; Ralling 1978; and Ruse 1979: 164. Most of these authors, regardless of their dating of Darwin's conversion, argue that the finches provided Darwin with a decisive model for his general theory of evolution. As I have shown in more detail elsewhere, such claims are part of a considerable legend that has grown up around these famous birds (Sulloway 1982a). 
the Galapagos finches represent one another on the different islands of the archipelago..$^{32}$

Darwin's various published statements about the Galapagos finch localities have served to create even further confusion about his type specimens, a confusion that has helped to support the myth of his conversion during the voyage. Curators at the British Museum naturally assumed that Darwin's published locality information had come from his own finch specimens. Hence whenever Darwin indicated in the Zoology that a species had come from only one island, the curators subsequently entered that island on the labels of Darwin's type specimens. As time went on, it increasingly appeared that Darwin must have appreciated the evolutionary significance of the finches while he was in the Galapagos Archipelago, if he had gone to the trouble of segregating all of his specimens by island. On the other hand, this circular derivation of the localities of Darwin's types largely accounts for the taxonomic nightmare the specimens have caused later ornithologists. Darwin's finches are generally differentiated into separate subspecies on the different islands, and each subspecies has measurably different ranges for wing length and bill size. If specimens are labeled with incorrect localities, as many of Darwin's subsequently were, they will inevitably appear somewhat anomalous in comparison with other specimens from that island. The dubious localities entered on many of Darwin's type specimens gave rise to vigorous debates among subsequent ornithologists about whether some subspecies of Darwin's finches had evolved since his visit to those islands! Fortunately, clarification of the borrowed nature of Darwin's localities has resolved these debates, together with certain related problems in the nomenclature of Darwin's finches (Sulloway 1982b).

The imprecise nature of Darwin's Galapagos finch localities is a large part of the reason why Darwin, contrary to legend, never mentioned these birds in the Origin of Species (1859). For without more accurate and extensive locality information, it was simply not possible to put these finches forward as a convincing example of speciation through

32. Contrary to Darwin's suggestive claims in the second edition of his Journal (1845:395), there is almost no geographic representation among Darwin's finches at the species level. Most species have long since spread to the other islands of the archipelago, and at least eight islands have nine or more of the thirteen species. Only two species actually represent one another on the different islands, but Darwin did not know of this instance. See Lack 1947:20; 1969:254; and, for a discussion of the various inaccuracies associated with Darwin's published accounts about the finches, Sulloway 1982a. 
geographic isolation. It is no wonder that Darwin was so excited and relieved in 1845 when he heard the results of Joseph Hooker's rigorous demonstration of geographic representation in Darwin's several hundred species of Galapagos plants. To Hooker he responded in July of that year, "I cannot tell you how delighted and astonished I am at the results of your examination; how wonderfully they support my assertion on the differences in the animals of the different islands, about which I have always been fearful" (1887, 2:22; italics added).

As for the claim that Darwin was immediately impressed by the morphology of the finches as a classic case of adaptive evolutionary radiation, nothing could be further from the truth. While in the Galapagos Archipelago Darwin was more impressed by the apparent differences than by the similarities among these unusual finch species. At the time he actually believed he was dealing with a highly diverse group having at least three or four separate subfamilies. For example, Darwin identified the cactus finch as an "Icterus," a genus in the family of orioles and blackbirds, and he mistook the warbler finch for a "wren" or warbler. ${ }^{33}$ In fact, Darwin correctly identified as finches only six of the thirteen species - less than half the present total - and he placed these six species in two separate groups of large-beaked and small-beaked Fringillidae. ${ }^{34}$ Furthermore, with the exception of the cactus and warbler finches, Darwin failed to observe any differences in diet among the various species, mistakenly believing that their diets were largely identical (1841:99-100). For this reason he could never argue that the different beaks of these finches were necessarily adaptive and therefore produced by natural selection. Thus there is no basis to the claim that Darwin had these finches in mind when he broached an evolutionary interpretation of the mockingbirds and the tortoises in his Ornithological Notes. ${ }^{35}$

33. See Darwin 1963[1836]:262-264; and Sulloway 1982a. For the contrasting claim that Darwin was initially impressed by the morphological similarity of the finches and thought them only varieties altered by their new environment, see Bowman 1963:107; Grinnell 1974:260-261; Ruse 1979:166; and Ospovat 1981:91.

34. Although John Gould (1837a) subsequently named thirteen species of Galapagos finches from Darwin's collections, Darwin did not, as is often mistakenly assumed, collect all of the thirteen species. He, in fact, collected only nine. Gould, who did the best he could with only a small sampling of these unusual birds, named four additional species based on specimens that are now considered subspecies or atypical examples.

35. Gruber (1974:130), Grinnell (1974:262), and Ruse (1979:166) are among those who have mistakenly considered this passage in the Ornithological Notes as applying to the Galapagos finches. 
It was in the wake of Darwin's failure to appreciate the evolutionary significance of the tortoises and the finches that he was inclined also to reject such an interpretation for the mockingbirds and to suspect that they were "only varieties." Nor were his doubts unjustified. Darwin had collected on only a few islands of the Galapagos group. He could not rule out the possibility that he had procured only the most extreme forms of one unusually variable species, the "type" of which would prove, when collected, to be intermediate among all the extremes. In addition, three of Darwin's four island forms of mockingbird (those from Chatham, Albemarle, and James islands) are all very similar in appearance (Fig. 4); and between them, Darwin and Gould at one time synonymized these three similar forms under one species. ${ }^{36}$ Although the Charles Island form is more noticeably distinct, even this form is ranked as a subspecies by some ornithologists. ${ }^{37}$ In the absence of evidence indicating whether these island forms would interbreed if they ever came into secondary contact, this opinion is not unreasonable.

The somewhat dubious systematics of the Galapagos mockingbirds raises one further point concerning Darwin's Galapagos experience. What was crucial to his eventual decision to accept the mutability of species was not really the mockingbirds or any other single group of Galapagos organisms. Rather, Darwin's appreciation of the mockingbirds required his concomitant appreciation of the Galapagos evidence as a whole. This was not possible, however, until he had been freed of the many misconceptions that he had entertained about these unusual organisms during his brief visit to the archipelago.

Similarly, it was not until Darwin's Galapagos collections were analyzed by systematists having access to large museum collections that the highly endemic nature of the various Galapagos forms finally became evident. It should be emphasized that Darwin had not visited the western coast of South America north of Lima. Hence he could not know with certainty whether the various Galapagos species were mostly new forms, found nowhere else, or merely colonists from the nearest

36. While on the Beagle, Darwin believed the Chatham and Albemarle forms to be identical (see earlier in this paper; also DAR 31.3: MS p. 342v). These forms are now considered subspecifically or specifically distinct. John Gould (1837d) later synonymized the Chatham and James forms of the mockingbird, which are now also considered subspecifically or specifically distinct (see note 37).

37. Davis and Miller (1960:447-448) recognize only one Galapagos species of mockingbird (Nesomimus trifasciatus), which they subdivide into nine insular races. Harris (1974:128), on the other hand, tentatively recognizes four species, of which Darwin collected three. 




Fig. 4. The type specimens of Darwin's Galapagos mockingbirds (Nesomimus). From top to bottom (in the order that Darwin collected them): the Chatham Island form ( $N$ trifasciatus melanotis), the Charles Island form ( $N$. trifasciatus trifasciatus), the Albemarle Island form ( $N$. trifasciatus parvulus), and the James Island form ( $N$. trifasciatus personatus). (Courtesy of the British Museum [Natural History ], Sub-department of Ornithology, Tring.)

points of land (Central America, Columbia, and Ecuador). During the voyage Darwin had clearly recognized the impossibility of reaching a decision on this point when he commented in his voyage Diary, "It will be very interesting to find from future comparison to what district or 
'centre of creation' the organized beings of this archipelago must be attached" (1933:337; entry of September 26-27, 1835). From the ubiquitous evidence of the recent geological origins of the Galapagos Islands, Darwin probably assumed that, like the tortoises, most other resident species were not indigenous at all, but instead had colonized the islands after their emergence from the sea. What was subsequently to jolt Darwin's creationist loyalties was the surprising discovery that the majority of the Galapagos species - although of American character - were not present anywhere on either of the two American continents.

Thus it was that Darwin, three months after leaving the Galapagos Islands, could ponder the unique character of the marsupial animals of the Australian continent and could conclude that such curious biogeographic evidence was no cause for rejecting the theory of creation. His voyage Diary records how one afternoon his thinking on this subject was interrupted by the sight of a species of ant lion belonging to the same genus as the European kind. "Now what would the Disbeliever say to this?" Darwin asked with regard to the theory of creation. "Would any two workmen ever hit on so beautiful, so simple, \& yet so artificial a contrivance [that is, the ant lion's conical pitfall and exquisite predatory adaptations]? It cannot be thought so. The one hand has surely worked throughout the universe. A Geologist perhaps would suggest that the periods of Creation have been distinct $\&$ remote the one from the other; that the Creator rested in his labor" (1933: 383). In short, Darwin's occasional "vague doubts" about species during the last year of the Beagle voyage remained just that, symptoms of an inquiring mind that sometimes sensed, but could not quite accept, the biogeographic difficulties that were later to convince him of the mutability of species.

\section{DARWIN'S FOSSILS AND THE LAW OF SUCCESSION}

The Beagle docked in Falmouth, England, on October 2, 1836, after a voyage of nearly five years. During the next two months Darwin visited his family and friends and arranged for the disposal of his scientific collections. Then, in mid-December, he took up residence in Cambridge in order to consult with his mentor, John Stevens Henslow, and to look over all of his geological specimens. He remained in Cambridge for the next three months, with the exception of two brief visits to London. During this period he began to look over and revise his voyage manuscripts, and he also prepared a paper on his geological findings (1837a). It was during this same interval that Darwin's voyage 
specimens began to receive detailed attention and analysis from the many specialists who had agreed to describe them.

Of all the Beagle collections, Darwin's South American fossil Mammalia excited the most immediate interest among London naturalists; and this was one group of specimens that Darwin had no trouble placing with systematists. With the promise of help from William Clift, who was not familiar with some of the fossil forms, Richard Owen soon agreed to describe them. In the first week of December 1836 Darwin accordingly deposited a large shipment of bones at the Royal College of Surgeons, where both Clift and Owen held appointments in the Hunterian Museum. ${ }^{38}$ By mid-December, when Darwin took up residence in Cambridge, Owen had already given these fossils a preliminary examination and had differentiated at least two new forms - the Toxodon and the Scelidotherium - from the bones previously identified by Clift as belonging to the Megatherium. "Casts of them will be distributed, and descriptions published," Darwin informed his cousin William Darwin Fox. "They are very curious and valuable: one head belonged to some gnawing animal [the Toxodon], but of the size of a Hippopotamus! and another to an Ant Eater [the Scelidotherium] of the size of a horse!" $(1887,1: 276$; letter of December 15, 1836). Darwin's genuine surprise and pleasure at the novelties that Owen's preliminary examination had revealed is evident from a candid confession he made to Owen in a letter of December 19: "I, at one time, began to think that the fossil bones would be as troublesome to me and as of little service as some other branches of my collection are likely to be. - But now I look back to the trouble I took in procuring them with great satisfaction." Another shipment of fossils, including "one very large bone (of a Mastodon??)" was still to be sent down from Cambridge, Darwin informed Owen in this same letter (Rossetti 1930:410).

Upon receiving the second shipment of Darwin's fossils in late December or early January, Owen lost no time investigating the new paleontological treasures. By mid-January, when Charles Lyell was impatiently pumping Owen for a summary of his results, Owen had succeeded in distinguishing two more extinct forms in Darwin's

38. In a December 7 letter to his sister Caroline, Darwin mentioned that he was nearly finished unpacking these bones at the Royal College of Surgeons. Darwin arrived in London on December 2 and must have delivered the bones shortly thereafter. See DAR 154, letter of "Wednesday Evening [December 7, 1836]" to Caroline Darwin; and de Beer 1959:7. 
collection, both of them new to science. He briefly described his paleontological findings in a letter to Lyell of January 23. The bones thus far examined, he reported, belonged to a "giant armadillo" (evidently the Scelidotherium, which was related both to the armadillos and to the anteaters); a species of Megatherium (or giant sloth); another closely allied form with an armor covering (the Glyptodon); and a gigantic rodent (the Toxodon) ${ }^{39}$ By this time Owen had also clarified the identity of Darwin's "Mastodon??" bones, which he now described to Lyell as " 2 cervical vertebrae, portions of femur, \& fragments of a Gigantic Llama! as large as a Camel, but an Auchenia [that is, llama] (from the plains of Patagonia)" (quoted in Wilson 1972:437). This fossil llama was noteworthy in two ways. First, it displayed affinities both to the European Palaeotherium (a pachyderm allied to the tapirs) and to the ruminant camels and llamas. Owen later described this fossil as being "in a remarkable degree a transitional form" (1840:55), a conclusion that was all the more extraordinary because Cuvier had previously ranked the ruminants and the pachyderms as the two most distinct orders among the Mammalia. ${ }^{40}$ The second noteworthy feature about Darwin's giant llama was the dramatic confirmation that it gave to the "law of succession," by establishing the existence in ancient times of a form now confined exclusively to South America (Darwin 1839:209).

The law of succession was of particular interest to Lyell. Apparently impressed by Owen's identification of Darwin's giant llama, Lyell responded to the January 23 letter with a series of further questions aimed at elucidating the evident relationship between the past and present fauna of South America. To the query "Any living rodent in S. America of large size?"” Owen affirmatively replied: "Largest rodent

39. During the Beagle voyage Darwin had misidentified and, in some cases, failed to distinguish between several of these fossil forms. He had mistakenly considered the Scelidotherium, for example, as "allied to the Rhinoceros" (1933:103). He had also believed that the Megatherium was armored, like an armadillo, an error that caused him to think his Toxodon bones were those of the Megatherium, since they were found in the presence of polygonal bony plates. This same misconception caused Darwin to erroneously identify as Megatherium bones two other fossil forms that were only later distinguished by Owen as the Mylodon and the Glossotherium. The general effect of these confusions during the Beagle voyage was to minimize the evolutionary implications of the diverse fossil forms. See Sulloway 1969:88-92.

40. Darwin later emphasized this transmutationist point in the Origin of Species (1859:329). 
now known living in S. America is Capybara, a swamp \& water animal wh[ich] is large as [a] hog" (undated personal communication, quoted in Wilson 1972:437-438). Lyell's preoccupation with the problem of organic succession was the outgrowth of an earlier observation he had made in the Principles of Geology. In the third volume of that work he had drawn attention to the issue in connection with certain newly discovered fossil marsupials from Australia. "These facts are full of interest," he had concluded, "for they prove that the peculiar type of organization which now characterizes the marsupial tribes has prevailed from a remote period in Australia" (1830-33, 3:144). Darwin's South American fossils had therefore provided a second major source of paleontological evidence in confirmation of this law, a source that was helping, moreover, to reinforce Lyell's still-controversial emphasis upon geological continuity in the earth's history.

So impressed was Lyell by Darwin's fossil discoveries that he decided to take the occasion of his February 17, 1837, address as president of the Geological Society to provide his colleagues with a synopsis of Owen's recent determinations. Having secured Owen's permission, Lyell reviewed the five extraordinary fossil organisms that Owen had thus far distinguished. He concluded by remarking:

These fossils ... establish the fact that the peculiar type of organization which is now characteristic of the South American mammalia has been developed on that continent for a long period, sufficient at least to allow of the extinction of many large species of quadrupeds. The family of the armadillos is now exclusively confined to South America and here we have from the same country the Megatherium, and two other gigantic representatives of the same family. So in the Camelidæ, South America is the sole province where the genus Auchenia or Llama occurs in a living state, and now a much larger extinct species of Llama is discovered. Lastly, among the rodents, the largest in stature now living is the Capybara, which frequents the rivers and swamps of South America and is of the size of a hog. Mr. Darwin now brings home from the same continent the bones of a fossil rodent not inferior in dimensions to the rhinoceros.

These facts elucidate a general law previously deduced from the relations ascertained to exist between the recent and extinct quadrupeds of Australia.... (1837:511)

Thus Darwin's entire fossil collection, Lyell announced, had dramatically 
confirmed the law that existing species have a close anatomical relationship with extinct species of large continents.

Just a year later, at the 1838 annual meeting, Richard Owen's spectacular paleontological researchers on Darwin's fossils were honored by his receipt of the Geological Society's highest award, the Wollaston Medal. After presenting Owen with the medal and reciting the striking support his fossil reconstructions had provided for the law of succession, William Whewell, the society's new president, also commended Darwin's scientific endeavors with the assertion: "I cannot help considering his voyage round the world as one of the most important events for geology which has occurred for many years" (1838:643). There is some irony in the fact that both Owen and Whewell were to be among Darwin's most outspoken opponents when, in the Origin of Species (1859), he finally presented the law of succession in an evolutionary context.

When did Darwin first learn about Richard Owen's preliminary findings and the law of succession that they had so strikingly confirmed? It seems likely that he initially became aware of these results at the Geological Society's 1837 annual meeting. Lyell had written to Darwin on February 13 asking him to attend this meeting and hear his presidential speech. In his letter, Lyell mentioned an earlier (January) discussion of Darwin's new theory of coral reefs but did not divulge the results of Owen's most recent paleontological investigations (Wilson 1972:442). Lyell apparently intended his impending remarks on Darwin's fossils, and on the extreme importance that he attached to Darwin's scientific labors on the Beagle, to provide a pleasant surprise for Darwin as he listened to Lyell's speech.

Darwin accepted Lyell's invitation and proceeded to London to hear the presentation. ${ }^{41}$ At this same meeting it was announced that Darwin had been elected to the council, a sign of his growing prestige. Thus by February 17, 1837, Darwin had definitely become familiar with the first of the three general classes of facts about his voyage collections that were to prove instrumental in converting him to the theory of

41. According to Wilson (1972:442n21) and Herbert (1974:248n99), Darwin did not attend this Geological Society meeting; but he is recorded as being present in the unpublished minutes. He also seconded a motion at the meeting. See "Ordinary Minute Book," 8 (May 1836 to Jan. 1838):219. In addition, Darwin's sister Catherine addressed a February 17 letter to him in London, hoping to catch him while he was staying at his brother's flat on $43 \mathrm{Gt}$. Marlborough Street. Darwin subsequently referred to Lyell's speech in a letter to his sister Caroline dated February 29, 1837. See DAR 154. 
evolution. The other two classes of facts, still in the process of being properly clarified and validated, involved the geographic replacement of living species by other closely related species - namely, on the South American continent and, more dramatically still, among the different islands of the Galapagos Archipelago. ${ }^{42}$ For the elucidation of these two additional aspects of his voyage collections, Darwin was greatly indebted to a series of able naturalists associated with the Zoological Society of London.

\section{DARWIN AND THE ZOOLOGICAL SOCIETY OF LONDON}

The importance of Darwin's contact with the various naturalists associated with the Zoological Society of London has rightly been emphasized by other Darwin scholars. ${ }^{43}$ Nevertheless, the precise nature and timing of Darwin's scientific communications with these men has remained problematical. Here I concentrate primarily on Darwin's association with the eminent ornithologist John Gould, because it was Gould who described the Galapagos birds, thereby setting the stage for Darwin's ultimate acceptance of the transmutation of species.

Darwin delivered his collection of birds and mammals to the Zoological Society of London on January $4,1837.44$ It seems likely that he made this delivery in person, since he was in London that day to give a paper before the Geological Society (1837a). In addition, he wrote a letter to the Zoological Society dated January 4 that was read that afternoon at a meeting of the society's council. According to the minutes of that meeting, Darwin's letter "announced a present to the Society of his entire Collection of Mammalia and Birds made during His Majesty's Surveying Vessel Beagle. It was ordered that the best thanks of the Society be returned to Mr. Darwin for his liberal and valuable contribution to its preserved Collections: and that his wishes with respect to the disposal of the duplicate specimens in this Collection,

42. See the quotation from Darwin's Autobiography at the beginning of this article.

43. See Grinnell 1974:261-263; Herbert 1974:244; 1980:11-12; and Kohn $1980: 73$. See also Sulloway 1969:99-102, 108; 1979:26-27;1982a:20-23.

44. A few of Darwin's ornithological specimens at the British Museum (Natural History), Sub-department of Ornithology, Tring, still record this date of acquisition on the labels. See, for example, Darwin's specimen of Dolichonyx oryzivorus (the American bobolink, a migrant species collected in the Galapagos), reg. no. 18815.1 .2394 . 
and to the mounting and describing of the same be strictly complied with." 45

The promptness with which the Zoological Society's naturalists began to exhibit and name Darwin's Beagle specimens testifies to the considerable interest that many of his new birds and mammals must have aroused among the members. At the next regular meeting for scientific business (on January 10), just six days after Darwin deposited his specimens, the various specialists attached to the society began to describe them. The event was of sufficient public interest to be reported in three separate newspaper accounts, as well as in the literary weekly, the Athenoum. The following is the story about the meeting that was carried in London's Morning Herald:

ZOOLOGICAL SOCIETY. - The ordinary meeting was held on Tuesday evening; W. B. Scott, Esq., in the Chair. On the table was part of an extensive collection of mammalia and birds, brought over by Mr. Darwin, who accompanied the Beagle in its late surveying expedition in the capacity of Naturalist, and at his own expense, a free passage only being allowed by the Government. Of the former there were 80 , and of the latter 450 specimens, including about 150 species, many of which are new to European collections. . . . Several species of the mammalia were explained by Mr. Reid, amongst which was a new variety of Felis [cat], named $F$. Darwinnia, with several opossums. Mr. Gould likewise described 11 species of the birds brought by Mr. Darwin from the Gallapagos Islands, all of which were new forms, none being previously known in this country. ${ }^{46}$

Shortly after reading this story in the Moming Herald, Darwin's sister Catherine wrote to her brother to congratulate him on the successful impression his scientific labors were making on the London naturalists. ${ }^{47}$

45. See the unpublished "Zoological Society Minutes of Council," 5:79-80.

46. The Morning Herald, January 12, 1837, p. 5 ; see also the Moming Chronicle, January 12,1837, p. 3 ; the Standard, January 12,1837, p. 2; and the Athenceum, January 21,1837 , p. 51 . The first three of these accounts, nearly identical in wording but different in length, are clearly the work of a single reporter. The account published in the Athenaum, which is somewhat shorter and differently written, draws on the earlier newspaper accounts. Felis Darwinit and several other members of this genus were actually described by William Martin (1837a), not James Reid. Rejd (1837) described a number of other quadrupeds from Darwin's collection, including a new species of opossum (Didelphis hortensis) and a young specimen of the viscache (Legostomus trichodactylus).

47. DAR 154; letter of January $15,1837$. 
According to the Proceedings of the Zoological Society, which provides a more detailed account of the society's meetings, the birds described by John Gould on January 10 were none other than Darwin's Galapagos finches. His curiosity evidently piqued by this unusual avian group, Gould had wasted no time in announcing the society's acquisition of "a series of Ground Finches, so peculiar in form that he was induced to regard them as constituting an entirely new group containing 14 species, and appearing to be strictly confined to the Galapagos Islands" (1837a:4). Gould showed that he fully appreciated the anomalous nature of this avian group when he observed that the extreme variation in size and form of the bill indicated a singular taxonomic reversal of that character from primary to secondary status. More important, Gould correctly surmised the extremely close affinities of these species, despite the remarkably diverse nature of the bills, and he therefore characterized them under one genus (Geospiza) and three closely allied subgenera (Camarhynchus, Cactornis, and Certhidea).

Two weeks later, at the next meeting of the Zoological Society, Gould continued his exhibition of Darwin's ornithological collection, proceeding to the birds of prey. Of six new species in this general category, two of them were from the Galapagos Islands. One, an owl, belonged to a genus of mundane distribution - Otus (Brachyotus) galapagoensis. The other, a curious species of hawk, presented affinities with two usually disparate groups - the buteos or true "buzzards," another worldwide form; and the caracaras or carrion-feeding hawks, a group peculiar to South America. Gould commented at some length upon the singular relation between structure and habits in this new species, as well as upon its pronounced sexual dimorphism:

Were I not assured by Mr. Darwin that the habits of this bird strictly coincide with those of the Caracara (Polyborus Brasiliensis), its mode of flight and cry being precisely the same, I should have been induced to regard it as rather belonging to the genus Buteo than to Polyborus; but as I have satisfactorily ascertained by a close investigation, it forms a beautiful intervening link between these genera, as is evidenced by the scaling of the tarsi and the produced form of the beak; while its habits place it within the limits of the latter genus.

It is on the authority of Mr. Darwin also that I rely for the assurance of the two birds above described being the male and the female of the same species, so great is the difference between them in both size and colour. (1837b:9) 
At this same Zoological Society meeting William Martin exhibited a new species of fox from Darwin's collection (Vulpes fulvipes, from the island of Chiloe) and a known species of armadillo (Dasypus hybridus).

During the subsequent meeting of the Zoological Society, which took place on February 14, George Robert Waterhouse described numerous species of South American mice from Darwin's collection, most of them new to science. Gould, continuing his exhibition of Darwin's birds, named two new swallows (including Hirundo concolor, a species from the Galapagos), two new species of goatsuckers, and a new species of kingfisher from the Cape Verde Islands. Then, on February 28, Gould declared that three of Darwin's four island forms of the Galapagos mockingbird were specifically distinct, and he named them Orpheus trifasciatus, $O$. melanotis, and $O$. parvulus.

By the beginning of March, Gould, who was proceeding through Darwin's ornithological collections by major avian groups, had exhibited and pronounced as new more than two-thirds of the species from the Galapagos Islands. Of all of the localities visited by Darwin, this one small archipelago was clearly proving itself to be an unrivaled source of zoological novelty, especially among the birds. Gould ultimately identified twenty-five of the twenty-six Galapagos land birds ( 96 percent) as forms new to science and confined exclusively to that archipelago. Moreover, three of the eleven waders and water birds, forms generally having wide geographic ranges, proved endemic to the Galapagos. No doubt Gould and the other members of the Zoological Society would have agreed with Darwin when he later remarked about the Galapagos in his Journal, "The natural history of this archipelago is very remarkable: it seems to be a little world within itself ..." (1839:454).

\section{Danwin's Scientific Communications with Gould}

Having finally completed the task of looking over his geological specimens in Cambridge, Darwin moved to London on March 6, 1837, in order to be near the various specialists who were working on his Beagle collections. Darwin's return to London brings us to the subject of his scientific association with the Zoological Society in early 1837 , and in particular to the question of when Darwin first learned of John Gould's various ornithological findings. One possibility is that Darwin, who made two trips to London between January and March, may have heard about these results sometime prior to his move there on March 6. This supposition is reinforced by the published accounts of the society's meetings. For example, John Gould's report at the January 24 meeting 
regarding the new species of Galapagos hawk (Polyborus galapagoensis) suggests that Darwin and Gould had talked in some detail about this species prior to that date. According to Gould, it was upon Darwin's personal assurance about the bird's unusual habits and extreme sexual dimorphism that he had altered his initial strong inclination to classify Darwin's specimens as two separate species in the genus Buteo rather than in Polyborus (1837b:9). Similarly, at the same meeting Martin had described the Chiloe fox and had referred to Darwin's observations concerning the animal's extreme tameness (1837b:11).

The only alternative to direct personal contact with Darwin as the source of such behavioral details would have been the catalogues of his specimens that Darwin had prepared during the last months of the Beagle voyage. The Proceedings of the Zoological Society is somewhat ambiguous about whether Gould and other systematists had access to these catalogues during the early part of 1837 . For example, Gould had remarked at the January 10 meeting that he could not enter "into any further details respecting the species [of Galapagos finches] under consideration until Mr. Darwin had furnished him with some information relating to their habits and manners" (1837a:7). This information, insofar as it existed, was in the Ornithological Notes, suggesting either that this catalogue was not available to Gould at the time or that he mistakenly expected to receive additional information from Darwin at a later date. In any event, Darwin was by no means explicit in his Ornithological Notes about whether the male and female Galapagos hawk specimens were members of the same species. Furthermore, Gould's published account strongly implies that the information was communicated to him orally $(1837 \mathrm{~b}: 9)$. If this is true, Darwin and Gould must have discussed the Galapagos specimens prior to January 24 , most likely on January 4 when Darwin delivered the specimens to the Zoological Society.

The key to this problem of dating Darwin's scientific interchanges with John Gould, and his ensuing conversion, is provided by a curious discrepancy in the number of Galapagos finch species identified on January 10, 1837. According to the Proceedings, Gould named fourteen species. But three contemporaneous accounts give the number as eleven. ${ }^{48}$ This discrepancy suggests that the Proceedings may have been altered after the meeting to include either new information or a change in Gould's views. In particular, Gould's discussion of the finches took place before he had had the opportunity to examine Captain Robert

48. See note 46 . 
FitzRoy's collection of birds, which was received by the British Museum on February 21 1837.49 Fortunately, the Zoological Society of London still possesses the original unpublished minutes of its 1837 meetings. They reveal that changes indeed were often introduced into the society's scientific reports before they were finally published in the Proceedings.

To begin with, John Gould is reported in the unpublished minutes for January 10 as naming only twelve species of Darwin's finches, which he distributed among three, not four, genera. He had failed to include Certhidea olvacea, the warbler finch, in the group ${ }^{50}$ - an understandable oversight, since Gould had just begun working on Darwin's collection and was proceeding through it by major avian groups. Upon cursory examination, Gould must have initially believed the warbler finch to have been a warbler; but after he had become more familiar with the Galapagos specimens, he evidently realized his mistake. ${ }^{51}$

Another discrepancy between the unpublished and the published minutes of the Zoological Society bears directly on the question of Darwin's contacts with Gould. The unpublished minutes for January 24 report that Gould actually named two separate species of hawks from the Galapagos Archipelago, placing them within the genus Buteo, not Polybonus. Thus Gould had yet to receive Darwin's verbal report about the Galapagos hawk's unusual habits. Nor did he have Darwin's

49. See "Zoological Accessions Aves 1837-1851-3," pp. 7-15: reg. nos. 1837.2.21.231-417; British Museum (Natural History), Sub-department of Ornithology, Tring.

50. See "Zoological Society of London. Minutes of Scientific Meetings Oct. 1835 to Aug. 1840," p. 120. There is still a discrepancy between the number of finch species reported as being distinguished in the three newspaper accounts (eleven) and in the society's "Minutes" (twelve). I believe that Gould, possibly prompted by discussions with other naturalists at the January 10 meeting, may have changed his mind after the presentation, splitting one of his eleven species into two. Since the minutes of the Zoological Society, as evidenced by the neat hand that recorded them, were not written down immediately, Gould could easily have had this change incorporated. It was the custom for the minutes of the previous meeting to be read, corrected, and approved at the next meeting of the society. Thus the minutes were probably not copied into the society's official record until two or three weeks had elapsed.

51. Gould had rectified his error by May 10, when he again brought Darwin's finches before the Zoological Society. (See "Zoological Society of London. Minutes of Scientific Meetings Oct. 1835 to Aug. 1840," p. 164.) It is likely, however, that Gould had already realized his mistake by early March, when Darwin arrived in London. 


\section{FRANK J. SULLOWAY}

assurance that the two specimens, a male and a female, were sexually dimorphic members of the same species! Gould's temporary error establishes that he had begun naming and describing Darwin's collection without access to the extensive behavioral information that Darwin possessed and had recorded in the Ornithological Notes. ${ }^{52}$ This situation apparently continued right up to February 28 , the last meeting before Darwin retumed to London. At that meeting Gould (1837d) named and described the three new species of mockingbirds from the Galapagos Islands. But he did not restrict their localities by island, apparently being uninformed about this most important aspect of their geographic distribution. Thus, contrary to the impression given by the Zoological Society's published Proceedings, Darwin's first substantial discussion of the Galapagos species with Gould did not come until after he had taken up residence in London in early March.

\section{The March Meeting}

Among Darwin's papers at the Cambridge University Library is a single sheet of paper that appears to record the details of his early March meeting with John Gould (Figs. 5 and 6). This document, which measures $20 \times 32 \mathrm{~cm}$, is written in ink on both sides in a somewhat hurried hand. Primarily a record of Darwin's Galapagos species, and later labeled "Galapagos" vertically in pencil on both sides, the sheet in question also records several of Gould's other taxonomic judgments made during January and February of 1837 . Indeed, the sheet records evidence relating to the two classes of facts - geographic replacement among closely allied continental and Galapagos species - that ultimately precipitated Darwin's conversion to the theory of transmutation.

The list begins with a review of the species from the Galapagos Archipelago. The land birds are recorded in almost precisely the same order, and with the same commentary about their American continental alliances, as in Darwin's Journal (1839:461-462). Hence these notes must have been used later in preparing that work for publication. On

52. Darwin, who in the winter and spring of 1837 was just beginning to revise his voyage Diary for publication as his Joumal of Researches (1839), must have decided to keep certain of his voyage catalogues with him in order to copy portions into his Joumal. Relevant to this apparent decision was the fact that several of these catalogues (especially those for birds and animals) contained discussions that were lacking or only available in an earlier, unrevised format in his voyage zoology diary. 
Darwin's Conversion

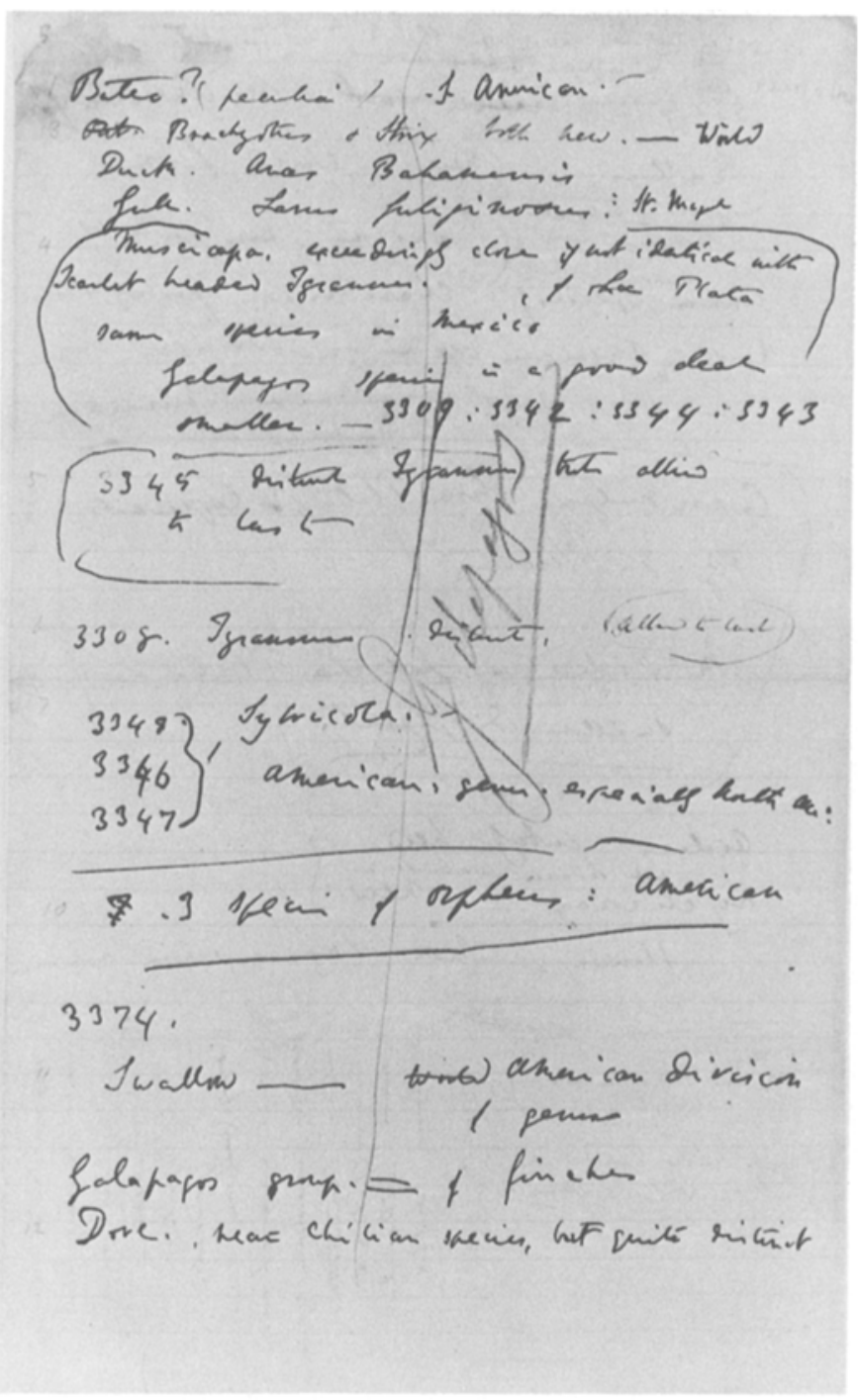

Fig. 5. Darwin's manuscript record of John Gould's Galapagos species designations (front). (Courtesy of the Syndics of Cambridge University Library.)

the reverse side, near the end of the list of Galapagos species, is a reference to four new species (two goatsuckers and two swallows) from the South American continent. Three more Galapagos species (all 


\section{FRANK J. SULLOWAY}



Fig.6. Darwin's manuscript record of John Gould's Galapagos species designations (back). (Courtesy of the Syndics of Cambridge University Library.)

waders) follow. At the bottom of the page, written sideways, are Gould's names for the various species of Darwin's finches. Three summary memoranda, evidently written at a later date, conclude the list. The first memorandum reads " 26 true land birds, all new except 
one: rallus." 53 The second reads "Capt Fitz Roy['s] Parrot beaked finch [Camarhynchus psittacula] comes from James Is] ${ }^{\mathrm{d}}$." The third comment, written in pencil and then erased, is only barely perceptible. It says "No specimens [or 'species"?] from James Island" and apparently refers either to Geospiza nebulosa or to Camarhynchus crassirostris on the list of finches. These last two memoranda reveal Darwin's initial attempts to extend to the finches the pattern of geographic speciation that Gould had recently confirmed in the case of the Galapagos mockingbirds. Hence these remarks about the finches bear unmistakable witness to Darwin's adoption of an evolutionary allegiance sometime after his meeting with Gould.

Several points of evidence indicate that the document under discussion could not have been written any earlier than March 6 or any later than May 10, 1837, although I shall narrow this range considerably based on other evidence. To begin with, the list records the rare Galapagos barn owl (Strix punctatissima) and the greater flamingo (Phoenicopterus ruber), also found in the Galapagos. Only FitzRoy's collection had included specimens of these two species; and FitzRoy's collection did not go to the British Museum, where Gould must have examined it, until February 21, 1837. In addition, Darwin's list records the three species of Galapagos mockingbirds (Orpheus), which had only been described by Gould on February 28. Therefore the document must have been written after Darwin's arrival in London on March 6 . An upper limit to the dating of this document is indicated by the record of the thirteen species of Darwin's finches. By May 10 Gould had added a fourteenth species to the group (Geospiza incerta), so the list clearly predates that change. ${ }^{54}$

53. See DAR $29.3: 27 \mathrm{v}$. This comment was initially written, like the numbers preceding all the land birds, in pencil. It was later written over in ink. As Darwin's list clearly indicates, the "rallus" or Galapagos rail (Zapomia spilonota) was not the one nonendemic species, so it is unclear what Darwin had in mind when he cited this bird in this context. At the time his Journal finally went to press (August 1837), Darwin and John Gould believed the one nonendemic Galapagos species to be the vermillion flycatcher (Pyrocephalus nubinus). Later, Gould changed his mind, declaring this form to be new and confined to the Galapagos. The "Finch with stiff tail, long claw, closely allied to the N. American genus Ammodramus" (item 13), was initially thought by Gould to be new. It tumed out, however, to be a migrant specimen of the American bobolink (Dolichonyx oryzivorus), a species already described. In 1838 Darwin added a footnote to the "Addenda" section of his Journal, which was printed later than the main text, in order to correct this error $(1839: 628)$.

54. See "Zoological Society of London. Minutes of Scientific Meetings Oct. 
From other evidence, internal and external, it is possible to infer that the document in question records the details of a meeting between Darwin and Gould that took place at the Zoological Society, most likely during the six days between March 7 and $12 .^{55}$ That this meeting occurred at the Zoological Society may be deduced from the nature of the paper on which Gould's taxonomic judgments are recorded. Except for an identical sheet in the Darwin manuscript collection, the paper, which is thinly ruled and bears a "Rewe Mill 1836" watermark, is unlike anything ever used by Darwin. The other identical sheet contains a list of the specific names proposed for Darwin's Beagle collection of mice. In the hand of George Robert Waterhouse, it constitutes a report on the species that Waterhouse had brought before the Zoological Society on February 14 and $28,1837 .^{56}$ Like Gould, Waterhouse was closely associated with the London Zoological Society and had recently assumed Gould's job as curator when Gould resigned it in order to spend more time preparing a book on Australian birds. The identity of the paper used to record their respective taxonomic judgments strongly suggests that this was a variety of notepaper then being used at the society. This interpretation is reinforced by the small drawing of an

1835 to Aug. 1840," p. 164. As late as July 30,1837, in a letter to Charles Lyell, Darwin indicated his belief that there were twenty-seven species of Galapagos land birds - in other words, fourteen finches and thirteen other land birds (see Wilson 1972:445). By this time Darwin had concluded the writing of his Journal, which was about to go to the printer. Hence his "Galapagos" list, which was used to add ornithological details to the Journal, must have been composed prior to this time, as well as prior to the increase in the number of finches species on May 10 Darwin's Journal (1839:461) correctly records the number of endemic Galapagos land birds as twenty six species and the number of finches as thirteen species. Either Darwin derived these figures from the "Galapagos" list and forgot to add the temporary fourteenth finch species, or else he corrected the text later when proofreading the galleys.

55. In a March 12 letter to his cousin William Darwin Fox, Darwin indicated that he had recently seen Gould and that together they were going to read a paper on Rhea darwinii at the March 14 meeting of the Zoological Society. See Darwin's unpublished letters to William Darwin Fox, Christ's College Library, Cambridge, England.

56. See DAR 29.3:44. This document was written sometime after February 28,1837 , since Waterhouse had already changed his mind about several of the specific names proposed earlier in the society's unpublished minutes. The document clearly predates the published versions of Waterhouse's descriptions (1837a and $b$ ), because several of the names were changed again. See "Zoological Society of London. Minutes of Scientific Meetings Oct. 1835 to Aug. 1840," pp. 129, 135-136. 
animal that appears on the back of Darwin's record of his meeting with Gould.$^{57}$ The drawing, apparently made by Gould or some other naturalist at the society, was subsequently written over in ink when Darwin recorded Gould's ornithological judgments. Darwin must have asked Gould or another zoologist working at the society for a piece of paper on which to record the details of his discussion with Gould. Having received this nearly blank sheet with the small drawing on one side, Darwin proceeded to take notes on it, using the blank side first. The oral nature of his ensuing conversation with Gould is clearly indicated by the telltale misspelling of the twelfth species of Darwin's finches (the silent $p$ is omitted from the name psittacula).

From several points of evidence we may gather that this discussion took place in early March, shortly after Darwin's arrival in London. First, had Darwin waited until April or early May, the latest this list could have been compiled, it is quite unlikely that he would have bothered to record the four non-Galapagos species (two goatsuckers and two swallows) that Gould had named on February $14 .^{58}$ In fact, Darwin's list appears to be a summary of the bulk of Gould's taxonomic judgments up to the beginning of March. Of the twenty-nine species, both from the South American continent and from the Galapagos, that Gould had named prior to Darwin's move to London, twenty-three of them (or 79 percent) appear on Darwin's "Galapagos" list. On the other hand, the list also contains references to several Galapagos species that Gould had not yet publicly discussed as of the beginning of March. I believe that Darwin, whose interest must have been greatly aroused by Gould's initial reports on the Galapagos species already named and described, asked him in early March to review the Galapagos collection as a whole. This circumstance would account for the tentative nature of Gould's pronouncements about several species he believed to be "probably new," as well as for his failure to provide specific names for most of these as-yet-undescribed species.

There is one further detail about Darwin's "Galapagos" list that

57. According to various mammalogists who have examined this drawing for me, it appears to depict a hedgehog. It could also represent a young dog, a skunk (but not the South American form, which has a long snout), or even a lemur. None of these possibilities appears to have any reference to Darwin's collections.

58. Although the published proceedings of the society indicate that only one continental species of swallow was named on February 14, the unpublished minutes record the naming of two species. See Gould (1837c) and "Zoological Society of London. Minutes of Scientific Meetings Oct. 1835 to Aug. 1840," p. 129. 
strongly suggests a dating of early March: the very first entry on the list, "Buteo? (peculiar)." This entry is clearly in response to Gould's own January 24 classification of this species in the genus Buteo, a judgment Darwin evidently questioned at their meeting owing to his own knowledge of the bird's behavior. ${ }^{59}$ Gould must have begun by informing Darwin of his Buteo classification, at which point a muchsurprised Darwin responded along the lines later indicated in the Zoological Society's published Proceedings. Darwin's testimony about the bird's habits cast the whole matter into doubt (hence his reference on the list to "Buteo?"). This circumstance must have prompted Gould's subsequent comparison of the Galapagos hawk with the various caracaras in the society's museum. Having become convinced that the species indeed approached the caracaras in several important morphological features, Gould acceded to Darwin's judgment and reassigned the species to the genus Polyborus (1837b). It is unlikely that Gould, whose public discussion of this species had been called into serious question by Darwin's remarks, waited long to correct his classification following his first meeting with Darwin. Had Darwin recorded the list of Galapagos species after that reassignment, his reference to the Galapagos hawk would not have been to "Buteo?" but rather to "Polyborus" or "Polyborus?" 60 All in all, the evidence

59. In his Ornithological Notes Darwin had grouped the Galapagos hawk with the other South American "caracaras" and had referred to it by that name (1963 [1836] :238-239).

60. As it tums out, Gould was seriously misled by Darwin's behavioral description of the Galapagos hawk, which is structurally a Buteo and is now classified in that genus (Amadon 1965:9-11). In the Zoology of the Voyage of H.M.S. Beagle Gould later changed his mind about classifying this species in the genus Polyboras. His solution was to place the species in its own monotypic genus Craxirex (1841:23). Darwin, however, ultimately reached the most accurate understanding of this species, based on an evolutionary point of view. In his first notebook on the transmutation of species he wrote of the "principle of animal having come to island where it could increase, but there were causes to induce great change, like the Buzzard which has changed into Caracara at the Galapagos" (de Beer et al. 1967: B 55e). Later, in his Journal of Researches, Darwin asserted that "it might be fancied that a bird originally a buzzard, had been induced here to undertake the office of the carrion-feeding Polybori of the American continent" (1845:380). The structural similarities between Buteo galopagoensis and the Polyborinae are actually quite minimal and purely a case of convergent evolution. It is particularly in such instances that the theory of evolution allows a better understanding of systematics than was possible under the creationist point of view. 
suggests that Darwin's manuscript list of Galapagos and mainland species records the details of a meeting with John Gould in early March 1837 , when matters of nomenclature and the systematic affinities of some of the species were temporarily in doubt.

In any event, the "Buteo?" entry confirms the judgment that Darwin and Gould were not in close contact with each other about the Galapagos species until Darwin moved to London. Early March of 1837 is therefore the first opportunity Darwin had to find out how truly remarkable the organic productions of the Galapagos Archipelago were proving to be. From Gould he had learned that virtually all the Galapagos land birds were unique, although clearly of American character, and that some of these species indeed represented one another on the different islands of the archipelago. It is undoubtedly this circumstance that accounts for Darwin's subsequent entry in his pocket joumal: "In July opened first notebook on 'Transmutation of Species' - Had been greatly struck from about Month of previous March on character of S. American fossils - \& species on Galapagos Archipelago. These facts origin (especially latter) of all my views" (de Beer 1959:7).

Darwin's scientific contacts with Gould at this time appear to have been the final catalyst in his conversion to the theory of evolution. But if Gould's clarification of the Galapagos evidence was especially important in breaking down Darwin's confidence in the "species barrier," it was the evidence of fossil succession and representative species from the South American mainland that apparently prompted Darwin to accept the unlimited transmutation of species over large geographic areas and through vast periods of geological time. For it was in March of 1837 that these other two classes of evidence, repeatedly cited by Darwin along with the Galapagos case in later accounts of his conversion, also came together in his thinking within an evolutionary framework.

As Darwin's pocket journal implies by the phrase "from about Month of previous March" in dating his conversion, there probably never was a single moment when he suddenly converted to the theory of evolution, following his ornithological discussions with John Gould in early March. But if the conversion was not instantaneous, it probably did not take more than a few days or a week at most. And even this relatively brief episode of intellectual transformation had itself been foreshadowed by occasional "vague doubts" about species over the previous eighteen months or so. In this sense the conversion was, and remained, an ongoing process and was not the sort of dramatic or instantaneous insight that legend has generally maintained. 


\section{THE "RED NOTEBOOK"}

Following his acceptance of the transmutation of species in early March of 1837, Darwin lost little time in pursing the new ideas and evidence that were associated with this conceptual transformation. In a letter to Henslow dated March 28, Darwin asked his former teacher, who had taken charge of his collection of plants, to tell him what was "the general character" of the Galapagos flora. In that same letter Darwin also requested that Henslow ask his brother-in-law Leonard Jenyns, who had agreed to describe the fish, if he would look at the Galapagos portion of the collection first (1967:126). Thus by the end of March the case of the Galapagos Islands had become of special interest to Darwin, who was evidently anxious to probe it as deeply as his various voyage collections would allow. In a letter to Henslow postmarked May 18, Darwin even proposed that they should publish the botany of the Galapagos as part of the Zoology of the Voyage of H.M.S. Beagle in order to consolidate "materials for any general result[s]" (1967:129). What Darwin undoubtedly had in mind, and had probably already tried to confirm in the case of the Galapagos finches, was the geographic representation of species found on the different islands.

Sometime after his early March meeting with John Gould, Darwin also began to record in a small pocket notebook his growing thoughts on the transmutation of species. Known as the Red Notebook, this document is the last of a series of red leather-bound notebooks that Darwin kept during the Beagle voyage. It has been transcribed and edited by Herbert (1980), who dates the beginning of the notebook to the last few months of the voyage and places its completion around May or June of 1837. The Red Notebook therefore spans the interval between the end of the Beagle voyage and July 1837, when Darwin began his first notebook on the transmutation of species.

The dating of the evolutionary passages in this notebook has remained somewhat problematic. Herbert provides a variety of indirect evidence that would give these passages "an approximate dating of March 1837" (1980:11). ${ }^{61}$ Unfortunately, none of this evidence is

61. Herbert (1980:6-12) supplies four general kinds of evidence for dating the crucial evolutionary passages (pages $127-133$ of the Red Notebook) to about March. First, the reference to an "extinct Llama" on page 129 could not have been written prior to Richard Owen's examination of this fossil form at the end of January 1837. In addition, page 143 of the Red Notebook refers to the April 
absolutely conclusive, and the passages in question could have been written, as Herbert acknowledges, any time between late January and early July. The evidence that I supply here narrows that range considerably and permits a more precise dating of the notebook as a whole.

The first of Darwin's transmutationist speculations in the Red Notebook deals with a theoretical difficulty and a theoretical generalization, both of which appear to have been inspired by the example of the Galapagos Islands:

Speculate on neutral ground of 2 ostriches; bigger one encroaches on smaller. - change not progressif: produced at one blow. If one species altered: Mem: my idea of Volc: islands. elevated. then peculiar plants created [by colonization and ensuing transmutation] . if for such mere points, then any mountain. one is falsely less surprised at new creation for large [areas].- Australias $=$ if for volc. isl ${ }^{\mathrm{d}}$. then for any spot of land. = Yet new creation affected by Halo of neighbouring continent: $\neq$ as if any creation taking place over certain area must have peculiar character: ... (Darwin 1980[18361837] :127-128)

The two general issues that are raised in this Red Notebook passage both involve the phenomena of geographic distribution. By early March 1837 the evidence provided by the Galapagos Archipelago had given

29, 1837, issue of the Athenaum, suggesting that pages 127-133 were written sometime prior to this date. Another entry near the end of the notebook (page 178) can be associated with conversations Darwin was having with botanist Robert Brown in April or early May. Second, the subject matter of these evolutionary passages corresponds to some extent with Darwin's later claim that he "Had been greatly struck from about Month of previous March on character of S. American fossils - \& species on Galapagos Archipelago" (de Beer 1959:7). (Nevertheless, the Red Notebook does not actually mention the Galapagos Archipelago or its species.) Third, the evolutionary passages of the Red Notebook clearly predate the more sophisticated arguments of the first notebook on trans mutation of species, begun in July 1837. Fourth, March is the month that can be associated with Darwin's contact with the various specialists who were working on his collections, and this information appears to have been important in Darwin's acceptance of transmutation. Herbert does not, however, indicate a direct tie between the Red Notebook and the determinations of the London naturalists. Nor has she established that Darwin first had access to this information in March of 1837 , rather than sometime during the previous two months. It is apparently for these two reasons that Herbert claims only an approximate dating of March for the first evolutionary passages of the Red Notebook. 
Darwin a paradigmatic example of speciation through geographic isolation. But the two closely related species of South American ostrich (Rhea) that Gould officially distinguished at the Zoological Society on March 14 were not separated geographically by any absolute barrier. As Darwin himself had reported at the same meeting, the two species of Rhea meet at the Rio Negro in northern Patagonia, which Darwin characterized at the Zoological Society as "neutral territory" (1837b:36). Both ostriches, however, are good swimmers, so the river itself poses no real obstacle for them. Hence Darwin was forced to consider whether complete geographic isolation was really necessary for successful speciation, and he concluded in this passage of the Red Notebook that some continental species might be formed without such isolation if "produced at one blow." This saltationist interpretation was almost unavoidable if Darwin was to explain how evolution could overcome the constant mixing of forms that would occur without geographic isolation. ${ }^{62}$

The second general issue raised in the Red Notebook passage deals with the unity of type that is customarily associated with geographic speciation over large areas. The organic inhabitants of the Galapagos Archipelago exhibit, as Darwin later stressed in his Journal of Researches (1845:393), purely American types of organization. Yet the Cape Verde Islands, which resemble the Galapagos Islands in both climate and physical conditions far more than the latter resemble the South American mainland, have their organic productions molded upon the African type of organization. This organic "Halo of [the] neighbouring continent," as Darwin described it in the Red Notebook, could be explained by the assumption that every isolated volcanic island emerging from beneath the ocean receives its first colonists from the nearest (usually continental) source of land. Should these colonists become altered after time and isolation, they would naturally convey the

62. Darwin was wrong on this point, since speciation cannot occur without virtually complete geographic isolation - except in the case of plants, which sometimes speciate abruptly by the unique genetic mechanism of polyploidy. Darwin never reached a satisfactory position on this issue, although he did abandon the saltationist notion that species can be "produced at one blow." What he particularly failed to appreciate was that representative species in contact with one another must have evolved under conditions of prior geographic isolation and then come into secondary contact after reproductive isolation was successfully achieved. For a review of Darwin's thinking about geographic isolation and its role in speciation, see Kottler 1978 and Sulloway 1979. 
appearance of a peculiar creation reflecting the geographic "plan" or "type" dominating the nearest large landmass. If this theoretical model could explain the case of volcanic islands, Darwin concluded, then it could also explain even larger, continental "creations" like the fauna of Australia, with its peculiar marsupial organization.

Almost immediately following this initial transmutationist passage in the Red Notebook, Darwin reminded himself to test the general applicability of this theory of geographic speciation on the other representative species in his South American collections: "Great contrast of two sides of Cordillera, where climate [is] similar. - I do not know botanically $=$ but picturesquely. ... Go steadily through all the limits of birds \& animals in S. America" (p. 128). Among the manuscript notes associated with the revisions of Darwin's voyage diary for publication, several such lists testify to his systematic follow-up of this reminder. ${ }^{63}$ Similarly, in his Joumal Darwin subsequently discussed the phenomenon of geographic representation among the species on the two sides of the Andes, and he even hinted at an evolutionary interpretation of the case. ${ }^{64}$

Another evolutionary insight in the Red Notebook involves an extrapolation of Darwin's thinking about geographic speciation to the problem of organic succession. Just a page after his memorandum to check the geographic ranges for South American birds and animals, Darwin confidently asserted:

63. These lists, together with other notes on Darwin's Beagle specimens, are mostly on paper watermarked "W. Fincher 1836." From the uniformity of the watermark and the fact that some of the sheets refer to the recent taxonomic judgments of various specialists at the Zoological Society, these notes may be assigned to the period between March 6 and the end of June 1837, when Darwin had pretty well finished his Journal. It is likely, however, that all of these notes were compiled in the latter part of March or in April rather than later, since they were relevant to his understanding of continental species distributions, a frequent topic in the first two-thirds of the Journal. See DAR 29.1:41, 45-47; and Herbert $1974: 248$.

64. In this discussion Darwin asserted that unless the same species had been created in more than one place, no greater similarity should be expected between the organic productions on two sides of an ancient mountain range than on shores separated by a large body of ocean. In a footnote to this passage he nevertheless added: "The whole reasoning, of course, is founded on the assumption of the immutability of species. Otherwise the changes might be considered as superinduced by different circumstances in the two regions during a length of time" $(1839: 400 \mathrm{n}$ ). This passage was probably drafted around mid-May of 1837 (see note 82 ). 
The same kind of relation that common ostrich bears to (Petisse. $\&$ diff[erent] kinds of Fourmillier): extinct Guanaco to recent: in former case position, in latter time. (or changes consequent on lapse) being the relation. - As in first cases distinct species inosculate [that is, adjoin geographically], so must we believe ancient ones [did] : $\therefore$ not gradual change or degeneration. from circumstance: if one species does change into another it must be per saltum - or species may perish. $=$ This [inosculation crossed out] representation of species important, each its own limit \& represented. - Chiloe creeper: Furnarius. [Caracara deleted] Calandria; inosculation alone shows not gradation; - (Darwin 1980[1836-1837]:130)

Here Darwin has reduced the evident bond among South American organisms, both in time and in space, to one and the same explanation: the affinity of common descent.

It is this insightful passage in the Red Notebook that provides perhaps the best evidence for dating the earliest expressions of Darwin's conversion to the theory of evolution. Of the six kinds of birds mentioned in this passage, one of them, the Calandria or mockingbird, indicates Darwin's knowledge of information that could only have come from John Gould sometime after March $6 .{ }^{65}$ Furthermore,

65. During the Beagle voyage Darwin had recognized the specific distinctness and separate geographic ranges of the two forms of ostrich $(R h e a)$; the fourmilier or antbirds (= Myothera in the Ornithological Notes and Pteroptochus in the Journal); the Chiloe creeper (Oxyurus tupinieri); and some, but not all, of the species of Fumarius and caracara in his collection. See Darwin 1963[1836] and Herbert 1980:111-115. Hence none of these examples were dependent on Darwin's communications with Gould. On the other hand, Darwin's deletion of the word "Caracara" from his Red Notebook passage probably does reflect his scientific contact with Gould. As he initially cited this avian form, Darwin was probably thinking of the way in which the caracaras were apparently represented in the Galapagos Islands by the Galapagos hawk. But since Gould, in early March of 1837 , had already insisted that the Galapagos species was a Buteo or true hawk, the whole case had been thrown into doubt. Hence Darwin, evidently thinking better of the matter, deleted this entry and picked what he considered a less debatable example (the "Calandria" or South American mockingbird).

The Red Notebook contains the first correct spelling of the name Calandria. During the Beagle voyage Darwin consistently spelled it Callandra (see note 14). This correction in spelling almost certainly derived from one of two sources with which Darwin came into contact after the Beagle voyage. The first was Azara's Voyages dans l'Amérique Méridionale (1809, 3:440-445), a work that Darwin did not possess on the Beagle and that he apparently first consulted sometime 
Darwin's citation of this particular species as an example of geographic replacement is in many ways indicative of the catalytic influence that Gould must have had on Darwin's thinking soon after his arrival in London.

During the Beagle voyage Darwin had collected mockingbird specimens at Maldonado, in Uruguay; to the south, in Patagonia; and at Valparaiso, on the west coast of South America. In his Journal of Researches Darwin later described the role Gould had played in clarifying the systematics of this group: ${ }^{66}$

A mockingbird, Orpheus modulator, called by the inhabitants Calandria, is remarkable, from possessing a song far superior to that of any other bird in the country. ... Near Maldonado these birds were tame and bold; they constantly attended in numbers the country houses, to pick up the meat which was hung up on the posts or walls.... On the wide uninhabited plains of Patagonia another closely allied species, $O$. Patagonica of D'Orbigny, which frequents the valleys clothed with spiny bushes, is a wilder bird, and has a slightly different tone of voice. It appears to me a curious circumstance, as showing the fine shades of difference in habits [among certain morphologically similar but distinct species], that, judging from this latter respect alone, when 1 first saw this second species, I thought it was different from the Maldonado kind. Having afterwards procured a specimen, and comparing the two without particular care, they appeared so very similar, that I changed my opinion; but now Mr. Gould says that they are certainly distinct; a conclusion in conformity with the trifling difference of habit, of which, however, he was not aware. $\quad(1839: 62-63)$

between March 6 and 14,1837, while preparing his paper on the rheas for the Zoological Society. The other possible source of the correction was a publication by d'Orbigny and Lafresnaye (1837), which Darwin would have learned about from Gould sometime after March 6, 1837. See note 68 .

66. Prior to March of 1837 Gould not only knew nothing about the different habits of these species, but he was also misinformed about the geographic range of Orpheus modulator, which he had previously named and described at the Zoological Society in early 1836 . The specimen that he had described in 1836 had been incorrectly labeled "Straits of Magelhaens," an error that Darwin rectified once Gould informed him of the distinct nature of his Patagonian and Maldonado mockingbird specimens. Thus Gould's separation of these two species without a knowledge of their habits was all the more remarkable, since he must have thought they had similar geographic ranges. 
Actually, Darwin's Ornithological Notes confirms that he had confused not just two, but three, distinct species of South American mockingbirds - all of the continental specimens in his collection. ${ }^{67}$ Hence the genus Orpheus, which Darwin had believed on the voyage to be represented by only two species (a continental and a Galapagos form), after the voyage became a highly paradigmatic example of geographic speciation with the four additional representative species that Gould was able to distinguish in Darwin's collections.

That Darwin and Gould had not reviewed this case prior to Darwin's move to London in March 1837 is established by the following facts. First of all, Gould only discussed Darwin's mockingbirds at the Zoological Society on February 28, just six days before Darwin's return to London. By then Gould had certainly distinguished the Calandria from the Patagonian mockingbird, since Darwin later commented in the Zoology that "immediately upon seeing them" Gould had recognized the difference between these species without knowing anything about their habits or geographic ranges. ${ }^{68}$ Gould must therefore have learned about these other differences in early March when he and Darwin finally began to review his various taxonomic judgments. And only then did

67. See Darwin 1963[1836]:215, 226, 247, 254 (specimen no. 1213, = 0 . modulator from Maldonado; specimen nos. 1461 and 2011, $=O$. patagonicus from Patagonia; and specimen nos. 2169 and 2170, $=O$. thenca from Valparaiso). These three species are now classified in the genus Mimus (see Davis and Miller $1960: 445-447)$.

68. Although the unpublished minutes of the Zoological Society fail to specify the exact number of new mockingbird species that Gould distinguished on February 28, the March 4 issue of the Athenaum (p. 163) reported that the number was five. Since three of these five species were from the Galapagos, Gould must have distinguished two more new species from the continent. (He had already named the third continental species, Orpheus modulator, a year earlier [Gould 1836].) It is a curious fact that Gould, who apparently recognized the two new continental mockingbird species on February 28 , named only the three Galapagos species at this meeting. There is, however, a possible explanation for this. Early in 1837 Alcide d'Orbigny and Frédéric de Lafresnaye had published descriptions of many of the birds collected by d'Orbigny in South America between 1826 and 1833 . The Zoological Society had recently subscribed to the magazine in which this article appeared (see Zoological Society 1838:8-9). Moreover, the first installment of this article, in which the authors distinguished Darwin's three continental mockingbird species, was completed by January and appears to have been issued shortly thereafter. Gould, who was notorious in his efforts to obtain priority in the naming of new species, would be likely to have named the two new continental mockingbird species on February 28 unless he had already lost that priority to d'Orbigny and Lafresnaye. 
Darwin learn that Gould had separated the three continental species that Darwin, until then, had assumed were identical. Hence Darwin's evolutionary interpretation of this case in the Red Notebook definitely postdates his return to London.

Darwin subsequently included the three continental mockingbird species on one of the distribution lists that he had reminded himself to draw up as a test of his new evolutionary views. Hence these lists, which appear to have been drafted in March or April ${ }^{69}$ reinforce the conclusion that the Red Notebook's earliest evolutionary passages were written soon after Darwin met with Gould in early March.

The Calandria is not the only guide in dating the earliest evolutionary passages of the Red Notebook. What is perhaps most striking is that the genera and species mentioned in the passages I have cited are precisely those that Gould and other zoologists had discussed and clarified immediately prior to, and just following, Darwin's return to London. The fossil llama, the two rheas, and the various mockingbird species were zoological subjects that must have been uppermost in Darwin's thoughts in early March 1837 . To these examples Darwin added several others in the Red Notebook (the antbirds, caracaras, Chiloe creeper, and various species of Furnarius) that he had recognized during the Beagle voyage as examples of geographic replacement. It is nevertheless significant that Gould identified two species of caracaras and three of Fumarius that Darwin himself had confused on the voyage with other geographic representatives. Moreover, the five additional species that Gould distinguished in these genera proved to be among the most dramatic demonstrations of geographic representation in Darwin's collections. ${ }^{70}$ Hence these additional instances, already partially known

69. See note 63 .

70. On the Beagle voyage Darwin had confused Milvago chimango from Maldonado with $M$. pezoporus from Patagonia and Tierra del Fuego. Similarly, he had confused $M$. albogularis from Patagonia with $M$. montanus from northern Chile. Of the eight species of "Furnarius," or ovenbirds, that Darwin collected during the voyage, he distinguished only five, obscuring the three best instances of geographic replacement. See Darwin 1963[1836]:213 (specimen no. 1028); 224 and 236 (specimen no. 1294); 229 (specimen no. 1772); 238, 248, and 260 (specimen nos. 2028 and 2029); 231-232 (specimen no. 1823); 233 (specimen no. 1931); and 260 (specimen no. 2827). See also Darwin $1841: 67-68$. Gould distinguished Milvago albogularis as a new species on January 24,1837 , and must have distinguished $M$. chimango from $M$. pezoporus at that time, since both were already described species. It is not known when Gould informed Darwin of the distinct nature of the three species of Furnarius that Darwin had previously confused, 
from the voyage, became greatly enhanced in their evolutionary meaning once Gould had clarified the systematics of Darwin's ornithological collections. Finally, it is certainly no coincidence that the various genera of birds that Gould was instrumental in clarifying in early 1837, and that Darwin then seized upon in the Red Notebook as evidence of the transmutation of species, continued to provide Darwin in his later works with some of his best examples of geographic speciation. ${ }^{71}$

Gould's rectification of so many of Darwin's taxonomic judgments underscores one final aspect of his influence on Darwin. As Herbert (1980:12) has pointed out, it was important for Darwin to learn just what a species was in the eyes of those who, like John Gould, were responsible for identifying this basic biological unit in the everyday practice of systematics and nomenclature. During the Beagle voyage Darwin had frequently come up against this question; and for lack of more specialized training and access to large museum collections, he had often deferred a final decision about which forms were species and which merely varieties. ${ }^{2}$ When confronted by the evidence of geographic replacement among extremely close species, Darwin had frequently lumped all of the relevant specimens together, either failing to note any differences at all or concluding that the different forms, like the Galapagos mockingbirds, were only varieties. By pointing out the many subtle morphological differences that often distinguish close species, Gould was able to persuade Darwin that some of Darwin's own field classifications had obscured much of the best evidence for geographic replacement.

but it certainly was no later than June 13,1837 , when he discussed this group at the Zoological Society and described three new species under that genus. See "Zoological Society of London. Minutes of Scientific Meetings Oct. 1835 to Aug. 1840," p. 174. If Darwin and Gould reviewed the collection as a whole in early March, it is likely that Gould had already distinguished most of these Furnarius species by then.

71. The genera Rhea, Orpheus, Furnarius (=Opetiorhynchus), and Polyborus (= Polyborus and Milvago) play a prominent role in Darwin's citation of evolutionary evidence in the furst two notebooks on the transmutation of species. See de Beer 1960-1961; and de Beer et al. 1967:B 7, 13, 37-38, 51e, 103, 105; and C 103, 126-127, 145, 208, 209e. See also Darwin 1909[1844]:83, 158, 161; 1975 [1856-1858]:111; and 1859:349, 402 .

72. See, for example, Darwin's "Animals" catalogue, where he wrote in the summer of 1836: "Are the various specimens of Mice which I have collected varieties or species? Their geographic distribution often causes me to doubt. - " (DAR 29.1: MS P. 31). This passage appears in a section added to the catalogue sometime after July 23, 1836, when the Beagle left Ascension Island. 
What ultimately impressed Darwin, however, was not so much the particulars of these various taxonomic decisions, but rather the general conception of "species" they entailed. Darwin and other naturalists might have disagreed with some of Gould's judgments, ${ }^{73}$ but Gould convinced Darwin that a firm line could be drawn, at least in some crucial instances. Darwin later raised this point in the Zoology, when he wrote of the Galapagos mockingbirds:

I may observe, that as some naturalists may be inclined to attribute these differences [among the three island forms] to local varieties; that if birds so different as $O$. trifasciatus and $O$. parvulus, can be considered as varieties of one species, then the experience of all the best ornithologists must be given up, and whole genera must be blended into one species. $\quad(1841: 63-64)$

It is likely that Darwin was here merely repeating what John Gould had said to him in March of 1837 when he asked if Gould was absolutely certain about the distinct nature of these insular forms. When Gould responded that "the experience of all the best ornithologists must be given up" if he was wrong in this case, Darwin at last had a firm standard against which to evaluate many of the compelling cases of geographic representation that had recently become available to him.

In concluding this discussion of the Red Notebook, I should like to point out several features of the notebook that help to confirm and refine the March dating I have provided for its evolutionary passages. The notebook was begun sometime around late May or early June of 1836, as Herbert (1980:6) has shown by correlating the subject matter of the early part of the notebook with the route of the Beagle. The section through page 112 was written in pencil, with entries inscribed along the short dimension of the pages, parallel to the binding. After this point Darwin began writing, mostly in ink, along the longer dimension of the pages. Herbert argues, I think persuasively, that all of

73. On the arbitrary nature of certain of Gould's systematic judgments Darwin later commented in the Origin: "Many years ago, when comparing, and seeing others compare, the birds from the separate islands of the Galapagos Archipelago, both one with another, and with those from the American mainland, I was much struck how entirely vague and arbitrary is the distinction between species and varieties" (1859:48; see also 1975 [1856-1858]:115; and 1909[1844] : $82,197)$. 
the material through page 112 was written during the Beagle voyage. ${ }^{74}$ The reason Darwin initially wrote along the short dimension of the pages is that he was holding the notebook (and turning its pages) vertically, which is much easier for a right-handed person to do when making entries in the field. As soon as he returned to England and began using the notebook for reading notes and reflections, often at a desk, he evidently turned the notebook around and began to write horizontally across the long dimension of the page.

An important unanswered question is when it was that Darwin began to use the notebook again after he had returned to England. Fortunately, the very first page (113) of the second part of the notebook gives us an important clue: it mentions the fossil "camel" from Patagonia that Darwin had only learned about in February of 1837. This entry was apparently in response to Darwin's attendance at the Geological Society's annual meeting on February 17. Thus during the four and one-half months between the end of the voyage and the annual meeting, Darwin did not use the Red Notebook at all. This pause in his notebook-keeping habits is not surprising, for the interruption came at a time when his scientific work was curtailed by visits to family and friends, as well as by efforts to dispose of his voyage collections. It was only after the first of the year, when Darwin began to present scientific papers and revise his voyage manuscripts for publication, that he again felt the need for a notebook in which to record memoranda and ideas. Apparently the February 17 meeting, at which Darwin received the first of an important series of communications about his voyage collections, triggered the actual reopening of the Red Notebook.

74. In confirmation of this point, Darwin spelled the word occassionally with a double $s$ on page 93, and the word Pacifick with a $k$ on page 97, nearly at the end of this voyage section of the notebook. Pages 93-94 of the Red Notebook refer to observations made at Pernambuco, Brazil, which Darwin visited between August 12 and 17, 1836. Hence pages 93-94 of the Red Notebook were written after August 12 and before the spellings of occassionally and Pacifick were both corrected, which was sometime during the next six weeks (see Table 1). On page 107 of the Red Notebook Darwin used the word occasion, spelled correctly. Since Darwin also referred on that page to the Azores, which the Beagle visited on September 25 , the last five pages of the voyage portion of the Red Notebook may be dated to the last week in September, just before the Beagle docked at Falmouth on October 2. Darwin filled the Red Notebook on the voyage at a fairly regular rate (about twenty-eight pages per month). Hence the final nineteen pages between 93 and 112 may be tentatively dated to about the last three weeks of September. Herbert (1980:56) has omitted the double $s$ in occassionally on page 93 of the Red Notebook, but the double $s$ is clearly there in the original. See the Red Notebook, Down House, Downe, Kent, England. 
In corroboration of this supposition, a personal communication from Charles Lyell about a letter he had received from John Herschel appears only two pages later (page 115). From the last three weeks of January until early March, when Darwin finally moved to London, he saw Lyell only once - at the Geological Society meeting of February 17. The proximity of the two Red Notebook entries strongly suggests that both were in response to that meeting.

The next sixtyeight pages of the Red Notebook were therefore apparently written during the four and one-half months between February 17 and the beginning of July, when Darwin started the $A$ and $B$ notebooks. Because several of these pages could not have been written before or after certain dates between March and July, it becomes possible to provide a likely sequence of dates for the remainder of the notebook as a whole. The simplest way is to date the notebook on a forward basis, assuming a relatively even rate of filling the notebook between the end of February and the end of June. Although this procedure by itself cannot be regarded as more than a guide, it does place all of the crucial entries in a reasonable temporal sequence that agrees nicely with independent evidence concerning Darwin's activities at this time. ${ }^{75}$

Following this sequence, the first nonevolutionary reference to Darwin's fossil camel (page 113) and the personal communication from Lyell (page 115) mark the reopening of the notebook on or shortly after February 17, but before Darwin had accepted the transmutation of species. The first evolutionary discussions (pages 127 and after), which clearly draw upon communications with Gould during the second week of March, are datable by proration to March $15 .{ }^{76}$ This is

75. I have, in fact, employed three different methods in dating the Red Notebook (pages 113-181). The first method is proration of the text between February 17 and the end of June 1837. The second method involves another form of proration, using references to subjects discussed in Darwin's Journal of Researches (see note 79 ). The third method involves evidence associated with Darwin's activities from January to early July 1837 (his attendances at scientific meetings, his reports of his activities in letters, and so forth). In many of the instances discussed in the text, datings can be corroborated independently to within a week (or even a few days) by all three means.

76. The earliest possible dating for these passages is March 6, when Darwin returned to London. It is unlikely, however, that Darwin met with Gould on the day of his arrival in London or that he recorded an immediate evolutionary response to their first meeting in the Red Notebook. Hence a lapse of a little more than a week between March 6 and 15 - sufficient time for Darwin to learn about, and fully appreciate, Gould's systematic work on the Galapagos species - is reasonably consistent with the dating by proration given in the text. 
the day after the Zoological Society meeting at which Darwin read his paper on the two rheas. In agreement with this general dating, the rheas and the geographic issue of their "neutral territory" figure prominently in the Red Notebook's first evolutionary discussions (page 127). On this same page an immediately preceding personal communication from Richard Owen also supports this March 15 dating, since Owen chaired the March 14 meeting. ${ }^{77}$ Other citations, a page earlier, are equally consistent. ${ }^{78}$ The remainder of the evolutionary passages (through page 133) would have been written by about March $28 .{ }^{79}$

A subsequent reference to the April 29 issue of the Athenceum agrees less satisfactorily with a projected date of April 17. Clearly this page, 143e, was written on or after April 29, most likely during the following few days, since the Athenoum was one of England's most

77. The reference to Owen involves the subject of small crustaceans living in salt lakes. This reference is written in pencil, unlike the evolutionary discussions that follow, and was apparently inscribed somewhat earlier than the remainder of the page, perhaps during the evening of March 14, when the topic probably came up.

78. This page (126) of the Red Notebook has a projected dating of March 13, the day before the meeting of the Zoological Society. On this page Darwin reminded himself to consult Azara (1809) and Sir Woodbine Parish about droughts in Argentina. Darwin had already familiarized himself with Azara's book, apparently for the first time, between March 6 and 14 as he was preparing his paper on the rheas (see note 65). Darwin would have seen Parish, a former chargé d'affaires in Buenos Aires, at the Geological Society on March 8 and would have expected to see him again at the next meeting two weeks later. Since both men had been elected to the Geological Society's council, Darwin would probably have discussed South American geology with Parish on March 8 and would naturally have looked to him for further information in this regard - hence his memorandum in the Red Notebook. Darwin later cited Azara's and Parish's views on the subject of Argentinian droughts in his Journal of Researches $(1839: 156)$.

79. A second and less precise method of dating this portion of the Red Notebook is worth mentioning here for its general agreement with the dates I have already suggested. Between pages 126 and 134 of the notebook are five references to subjects that Darwin discussed in his Journal of Researches between pages 77 and 208. Darwin began to revise that work in earnest in early March (de Beer 1959:7; and Darwin to William Darwin Fox, letter of March 12, 1837 [see note 55 ]). He kept steadily at this task until June 25 , when he finally finished. Prorating this Journal material over a four-month span (March 7 to June 25) gives an average date of March 25 for the two parallel sequences specified above, and approximate dates of March 19 through April 1 for pages 127 to 133 of the Red Notebook. This dating sequence, admittedly only an approximate one, is nevertheless within a few days of the independently derived sequence that I have proposed with more confidence in the text. 
widely read weeklies. ${ }^{80}$ In accordance with this supposition, a sudden rash of personal communications from members of the Geological Society of London appears between pages 142e and 145e. The Geological Society, which met on alternative weeks, held a session on May 3 . At that meeting Darwin delivered a paper on the geology of La Plata, where most of his fossil Mammalia had been found (1837c). One of the personal communications recorded between pages $142 \mathrm{e}$ and $145 \mathrm{e}$ of the Red Notebook deals with shell deposits near Buenos Aires. This entry was most relevant to, and probably prompted by, Darwin's May 3 talk. ${ }^{81}$

Darwin's only other discussion of an evolutionary nature in the Red Notebook, a passage that mentions the origins and geographic overlap between the two rheas, has a projected dating of May $20 .^{82}$ The passage reads:

80. On pages 141 and $142 \mathrm{e}$ of the Red Notebook Darwin mentioned topics that reappear on pages 253 and 303 of the Journal. Prorating the revisions of the Journal (see note 79) places these entries at about April 25, 1837, and page 143e of the Red Notebook at about April 28, in fairly close agreement with the April 29 issue of the Athenceum cited on that page.

81. There are five personal communications in this four-page sequence: two from Sir Woodbine Parish (including the one about shell deposits near Buenos Aires); and single communications from Roderick Murchison, Charles Lyell, and James Sowerby. Darwin, Parish, Murchison, and Lyell were all on the Geological Society council, and all but Parish attended the council meeting on May 3 ("Minutes of the Council. Geological Society of London," 4 [Dec. 1834 to Dec. 1837]:284). Parish, like other members of the council, frequently attended regular meetings of the society even though he did not attend council meetings of the same date. The Geological Society's "Ordinary Minute Book" does not record attendance at the Society's regular meetings, except in the case of guests and their sponsors. Parish may therefore have been present at the May 3 meeting, especially since Darwin's talk dealt with the geology of La Plata, an area in which he had great personal interest owing to his years of diplomatic service in Buenos Aires. Sowerby, who was not a member of the Geological Society, is not recorded as attending any meetings in May 1837, although he did deliver a paper before the society two months earlier (Sowerby 1837). If the majority of these personal communications were not in response to the May 3 meeting of the Geological Society, then they almost certainly took place at the society's next meeting (May 17). Darwin's reference to the Atheneeum issue of April 29 on page 143e of the Red Notebook, together with the subsequent contents of that notebook, makes the May 3 dating far the more probable.

82. Because page $142 \mathrm{e}$ of the Red Notebook must have been written after April 29 and also appears to be associated with the events of May 3, I have estimated dates for the remainder of the Red Notebook using a proration of subsequent text from this point in time. The general dating (May 20) that I have 
When we see Avestruz two species. certainly different. not insensible change. - Yet one is urged to look to common parent? why should two of the most closely allied species occur in same country? In botany instances diametrically opposite have been instanced.... (Darwin 1980 [1836-1837]:153)

Just ten days earlier (on May 10) Darwin had delivered a paper at the Zoological Society on his Galapagos finches (1837d). By this time he had probably already borrowed the Galapagos finch collections of his Beagle shipmates and tried to document the role of geographic speciation in the origins of the group. The theory of geographic speciation by isolation, then, would once again have been on his mind in mid-May. This circumstance was probably what prompted Darwin to make a brief allusion to the theory in his Journal of Researches when he discussed the distinct nature of the various species on the two sides of the Andes. ${ }^{83}$

The subject of coniferous fossil wood comes up on page 156 of the Red Notebook and has a projected dating of May 25. Seven days earlier Darwin had informed Henslow that his fossil wood specimens from the Uspallata range in Chile, recently examined by Robert Brown, had proved to be coniferous in nature (1967:127). On page 161 of the Red Notebook Darwin also mentioned having personally seen Brown's collection of fossil woods. (This passage has a projected dating of June 2.)

Finally, a reference (page 172e) to Erasmus Darwin's Botanic Garden, which has a projected dating of June 19 , can be associated with a letter written between the sixteenth and twentieth of that month. ${ }^{84}$

suggested for the passage about the rheas (page 153 of the Red Notebook) is independently corroborated by Darwin's discussions (on pages 151-154) of the Portillo line and the Uspallata range of the Andes. These subjects correspond to his Journal chapter "Passage of the Cordillera" (pages 382-415), the midpoint of which comes almost exactly two-thirds of the way through the book. In a letter to Henslow postmarked May 18, 1837, Darwin reported that he was "two thirds" through that manuscript (1967:128). (Page 403 of the Journal marks the twothirds point in the 1839 edition.)

83. This passage, in which Darwin wrote hypothetically that certain specific "changes might be considered as superinduced by different circumstances in the two regions during a length of time," has an approximate dating of May 18, 1837, just two days prior to the projected dating of the Red Notebook passage about the rheas. See notes 64 and 82 .

84. See DAR 154. I have dated the letter in question, which is an undated 
In this letter Darwin asked his sister Caroline whether it was in his grandfather's Zoonomia (1794-1796) or in his Botanic Garden (1789) that there was a discussion about crows' acquiring fear of guns. The query doubtless was prompted by Darwin's Joumal discussion of how land birds living on uninhabited oceanic islands gradually acquire a fear of man. This subject had come up in the concluding section of Darwin's Galapagos chapter, which he had finished revising by about the first of June. ${ }^{85}$ Darwin's mid-June letter to his sister contains another link to the concluding portion of the Red Notebook. Darwin referred to his father a query involving the possible puncturing of a live animal with an instrument already used to puncture a dead animal. A memorandum to conduct such an experiment appears on page 178 of the Red Notebook and has a projected dating of June $27^{86}$ This subject, along with

copy, from the general agreement of its contents with Darwin's revisions for his Journal around the middle of June and from Darwin's mention of his plans to visit Sir John Richardson in Chatham "on Thursday." On the assumption that Darwin would not have used the expression "on Thursday" if he had written the letter on either a Wednesday or a Thursday, the letter must have been written between June 16 and 20. Since Darwin saw Richardson at the Geological Society on Wednesday, June 14, Richardson probably tendered his invitation on that day ("Ordinary Minute Book," 8 [May 1836 to Jan. 1838]:403). Darwin's visit with Richardson must therefore have taken place on Thursday, June 22.

85. I infer that Darwin finished revising his Galapagos chapter by about the first of June from two points of evidence: (1) his report to Henslow that he was "two thirds" through the Journal on May 18 (see note 82), and (2) the fact that he finished the revisions of his Journal by June 25 .

86. This entry, along with another, is written upside down, suggesting that Darwin had reserved this page at the back of the notebook for memoranda. In this case the passage was probably written somewhat earlier than its projected dating by proration, as would also be expected on the basis of the similar and apparently earlier mention of this subject in his mid-June letter to Caroline. The same page bears one other entry, written right side up, that is clearly out of sequence. The passage constitutes a summary of Robert Brown's opinion about Darwin's fossil wood specimens from the Uspallata range in Chile, communicated to Darwin by May 18. Based on this passage Herbert $(1980: 9,12)$ has been misled, I believe, into thinking that the Red Notebook may have been completed by the end of May, a month earlier than my own dating. That Darwin, in writing this passage, jumped to the back of the notebook where he had reserved the last few pages for memoranda is reinforced by the fact that the following page (179) was left blank. The final two pages of the notebook (180 and 181) were reserved for an index and for lists of books read or to be read. In the later series of transmutation notebooks Darwin followed a similar policy of using the last few pages, often written from back to front, for memoranda and lists of books to be read. 
another medical question raised in his letter to Caroline, was treated in Darwin's Joumal chapter on Australia. Darwin would have been working on this chapter during the second week of June, prompting him to write to his sister during the following week in order to fill in the missing details. The Red Notebook comes to a close on page 181 and probably was completed near the end of the month. On June 26 Darwin, who had finished revising the Journal, departed for a short holiday in Shrewsbury. That vacation probably marked a brief interlude between the completion of the Red Notebook and the commencement of Darwin's first notebook on the transmutation of species sometime in July.

All in all, these estimated dates for various passages in the Red Notebook agree rather closely with Darwin's activities and intellectual preoccupations between February 17 and the end of June 1837. The proposed dates are, I believe, accurate to within a week in either direction; and in many cases they are probably within a few days of the actual dates. As for the earliest discussions on the transmutation of species (pages 127-133), they may be dated with some confidence to the last two weeks of March and clearly reflect the aftermath of Darwin's various communications with John Gould during the preceding week of that month. Hence when Darwin later wrote in his pocket journal that he had been "greatly struck from about Month of previous March on character of S. American fossils - \& species on Galapagos Archipelago," he was referring to the events of March 1837 and not, as some Darwin scholars have assumed, to those of the previous year. ${ }^{87}$

\section{CONCLUSION}

Darwin's conversion to the theory of transmutation has long been

87. See, for example, F. Darwin 1888:76; Poulton 1910:841; Barlow 1933: xiii; Gruber 1974:117; and Brent 1981:279. That Darwin was referring in his pocket journal to March of 1837 rather than 1836 is underscored by the fact that he composed the Ornithological Notes, which contains his most definitive voyage statement of doubt about the fixity of species, sometime between June 18 and July 19, 1836, not in March of that year. Darwin's choice of the peculiar phrase "Month of previous March" in referring to his July 1837 opening of the first notebook on the transmutation of species was probably dictated by the fact that he wrote this statement sometime after beginning his pocket journal in late 1838 . He therefore wanted to make it clear that the moment of real insight had come in March of 1837, "previous" to opening his first notebook on the transmutation of species, rather than a year later when he seems to have written this statement. See also Herbert 1974:234n51. 
shrouded in a popular mythology associated with his famous voyage around the world. The image of the lone traveler standing in the Galapagos Archipelago, observing at first hand that remarkable "laboratory of evolution," reinforces our empiricist and romantic conceptions of scientific discovery. The story of Darwin's voyage, together with its supposed intellectual culmination in the Galapagos Archipelago, has come to rank with Newton's experiences with the apple and Galileo's experiments at the Leaning Tower of Pisa as a classic account of scientific discovery. What such famous stories invariably obscure, however, is precisely what they pretend to convey: the nature of scientific insight. ${ }^{88}$

The Darwin who lies behind this legend of the Beagle voyage is a far more fallible and human figure than legend has allowed, a figure who was then in the process of a remarkable self-education and who still thought largely as he did before the Darwinian revolution transformed his voyage exploits into a heroic saga. When he began the Beagle voyage in 1831, Darwin was by no means "a finished Naturalist," as his teacher Henslow emphasized in proposing him for that post, but merely "amply qualified for collecting, observing, \& noting anything new to be noted in Natural History" (Darwin 1967:30). In particular, Darwin had little specialized knowledge of systematics when he left England, although he admittedly did have a rather impressive general knowledge about many branches of natural history. What knowledge he had of these various fields was nevertheless greatly restricted in its applicability aboard the Beagle by the novelty of many of the forms he collected and by his inability to compare his specimens with those in museum collections. It is not surprising, then, that Darwin was often plagued during the voyage by scientific and taxonomic confusion concerning the real significance of his specimens. This confusion partially accounts for his failure to appreciate, much less to accept, the bulk of the evolutionary evidence to which he was exposed as ship's naturalist.

Compounding Darwin's difficulties was the fact that he repeatedly read his creationist expectations into the evidence he was collecting. In doing so, he severely biased the later usefulness of his biological materials by the theory-dependent and often inadequate collection techniques he employed. Throughout the voyage Darwin collected only a few specimens (usually a male and a female) of each species, an almost unthinkable practice in light of the theories he later came to

88. On the role of such stories as exemplars of orthodox scientific methodology see Kuhn 1970:1 36-143; Cohen 1974:363, 366; and Brush 1974. 
accept. ${ }^{89}$ Even after visiting the Galapagos Archipelago, where he was repeatedly confronted by the evidence of geographic speciation, Darwin did not in any way alter his typological collecting procedures. Indeed, he was especially fortunate, as he later admitted (1839:629), to bring back sufficient evidence from the Galapagos to establish what few key generalizations he did. On some points, such as the presence of representative species on the different islands, it took him a whole decade after leaving the Galapagos to build a solid empirical foundation for his evolutionary suspicions.

Darwin's voyage deficiencies as a systematist and a collector should by no means be taken as an indictment. Rather, they provide a notatypical portrait of the way in which most scientific evidence is amassed. The scientist and his evidence are inextricably bound together; and much of good science, contrary to legend, consists in repeating observations and experiments once their significance has been grasped. The history of science is replete with such instances. To cite a relevant example, it took ornithologists almost a century to realize that the different beaks of Darwin's finches had an adaptive significance. Yet when David Lack (1947:vi) finally came to this novel conclusion, he had already completed his own researches in the Galapagos and had only suggestive and inconclusive evidence to support his contention. It was not until Robert Bowman's (1961) careful studies on this subject that the truth of Lack's important insight was established beyond doubt. Given the far greater theoretical handicaps under which Darwin was laboring in the Galapagos Islands more than a century earlier, it is hardly surprising that he too failed to observe much of the evolutionary evidence the islands had to offer.

A further contrast with the legend about Darwin's discoveries is provided by the record of his activities once he returned to England. His conversion to the theory of evolution did not spring full-blown as the result of his voyage, but emerged gradually in intimate cooperation with the numerous systematists who helped to correct many of his voyage misclassifications. What is perhaps remarkable above all else is that Darwin, and not the systematists who in the winter and spring of $1836 / 37$ so deftly exhibited their specialized superiority, became the

89. In his fourth notebook on the transmutation of species Darwin later commented in this connection that the "naming [of species from] mere single specimens in skins [is] worse than useless. - I may say all this, having myself aided in such sins" (de Beer 1960-1961:E 52). Darwin, of course, was only following the standard collecting procedures of his day when he settled for just a few specimens of each species. 
evolutionist once "the facts" were more clearly known. Darwin himself was so struck by this circumstance that he remarked more than once that there must be something antithetical between systematizing and generalizing. ${ }^{90}$ True or not, Darwin's supposition underscores a question about his conversion that has received surprisingly little attention. Why was he so impressed by the data that others apparently ignored or managed to interpret so differently? This question is made all the more compelling by the fact that Darwin subsequently published this evolutionary evidence in his Journal of Researches (1839) and in the Zoology of the Voyage of H.M.S. Beagle (1841), fully two decades before the Origin of Species (1859). And yet not one naturalist appears to have been converted to a belief in evolution by these earlier works. In hindsight it is easy to attribute the intellectual shortcomings of Darwin's scientific contemporaries to their prejudices, religious or otherwise. But such an appraisal, which implies that Darwin was somehow unprejudiced toward the evidence, is both unsatisfactory and misleading. Indeed, as long as it is believed that Darwin's eyes were opened by an unbiased reading of the book of nature, the most interesting source of his conversion is effectively obscured. That source is none other than Darwin himself; for it was he, and not the evidence per se, that ultimately imposed the unorthodox interpretations that led him to embrace the theory of evolution.

The remainder of Darwin's highly successful career in science reflects this characteristic pattern of gifted individualism that manifested itself in his conversion to the theory of evolution. ${ }^{91}$ Repeatedly the farseeing amateur among specialized experts, Darwin continued to do highly original work and to make important discoveries missed by his peers, in almost every major branch of natural history to which he turned. The secret of Darwin's continuing genius in science, like that of his conversion, appears to lie as much in Darwin as it does in the famous voyage he undertook, the unusual scientific evidence he encountered, or the many books he read along the way. We are thus brought face to face with the problem of scientific temperament and its intimate relationship to creativity in science. Indeed, this elusive subject becomes increasingly important to the historian of science as the romantic mythology commonly surrounding scientific discovery is at last dispelled.

90. See Darwin $1887,2: 40,379$.

91. On Darwin's intellectual individualism, see Ghiselin's (1971) valuable treatment. See also Sulloway (in press). 


\section{FRANK J. SULLOWAY}

\section{Acknowledgments}

I am grateful to the following persons and institutions for their assistance in connection with the preparation of this article: the Charles Darwin Research Station, Isla Santa Cruz, Galapagos Archipelago, where I was a visitor in 1968, 1970, and 1981-1982; Tjitte de Vries; Peter J. Gautrey; David Kohn; Malcolm Kottler; Robert Reynolds; Sydney Smith; and especially Ernst Mayr.

\section{REFERENCES}

Amadon, Dean. 1965. "Notes on the Galapagos Hawk." L'Oiseau et la revue française d'ornithologie, 35:9-21.

Azara, Félix de. 1809 . Voyages dans l'Amérique Méridionale . . . 4 vols. Paris: Dentu.

Barlow, Nora, ed. 1933. Charles Darwin's Diary of the Voyage of H.M.S. "Beagle." Cambridge: Cambridge University Press.

- 1935. "Charles Darwin and the Galapagos Islands [Letter to the Editor]." Nature, $136: 391$.

-, ed. 1945. Charles Darwin and the Voyage of the Beagle. With an Introduction by Nora Barlow. London: Pilot Press.

-, ed. 1963. Darwin's Ornithological Notes. With an Introduction, Notes, and Appendix by Nora Barlow. Bull. Brit. Mus. (Nat. Hist.) Hist. Ser., 2, no. 7.

--, ed. 1967. Darwin and Henslow: The Growth of an Idea. Letters 1831-1860. Berkeley and Los Angeles: University of California Press.

Bowman, Robert 1. 1961. "Morphological Differentiation and Adaptation in the Galapagos Finches." Univ. Cal. Publ. Zool., 58:1-302.

- 1963. "Evolutionary Patterns in Darwin's Finches." Occ. Pap. Calif. Acad. $S c i$., no. 44, pp. 107-140.

Brent, Peter. 1981. Charles Darwin: "A Man of Enlarged Curiosity." New York: Harper \& Row.

Broom, R. 1929. "On the Extinct Galapagos Tortoise that Inhabited Charles Island." Zoologica, 9:313-320.

Brush, Stephen G. 1974. "Should the History of Science be Rated X?" Science, 183:1164-1172.

Cohen, I. Bernard. 1974. "History and the Philosopher of Science." In The Structure of Scientific Theories, pp. 308-373. Edited by Frederick Suppe. Urbana: University of Illinois Press.

Dampier, William. 1729. A New Voyage Round the World. In A Collection of Voyages. Vol. 1. 7 th ed. London: James and John Knapton.

Darling, Lois, and Lewis Darling. 1963. Bird. With a Foreword by Niko Tinbergen. London: Methuen.

Darwin, Charles Robert. 1837a. "Observations of Proofs of Recent Elevation on the Coast of Chili, Made during the Survey of His Majesty's Ship Beagle, Commanded by Capt. Fitzroy, R.N." Proc. Geol. Soc. London, 2:446-449.

- 1837b. ["Notes upon the Rhea Americana and upon Rhea Darwinii."] Proc. Zool. Soc. London, 5:35-36. 
- 1837c. "A Sketch of the Deposits Containing Extinct Mammalia in the Neighbourhood of the Plata." Proc. Geol. Soc. London, 2:542-554.

- 1837d. "Remarks upon the Habits of the Genera Geospiza, Camarhynchus, Cactornis, and Certhidea of Gould." Proc. Zool. Soc. London, 5:49.

- 1839. Journal of Researches into the Geology and Natural History of the Various Countries Visited by H.M.S. Beagle, under the Command of Captain FitzRoy, R.N. from 1832 to 1836 . London: Henry Colburn.

-, ed. 1841. The Zoology of the Voyage of H.M.S. Beagle, under the Command of Captain FitzRoy, R.N., during the Years 1832-1836. Part III: Birds. London: Smith, Elder.

- 1845. Journal of Researches into the Natural History and Geology of the Countries Visited during the Voyage of H.M.S. Beagle round the World ... 2nd ed. London: John Murray.

- 1859. On the Origin of Species by means of Natural Selection, or, The Preservation of Favoured Races in the Struggle for Life. London: John Murray

- 1868. The Variation of Animals and Plants under Domestication. 2 vols. London: John Murray.

- 1887. The Life and Letters of Charles Darwin, Including an Autobiographical Chapter. Edited by Francis Darwin. 3 vols. London: John Murray.

- 1903. More Letters of Charles Darwin: A Record of His Work in a Series of Hitherto Unpublished Letters. 2 vols. Edited by Francis Darwin and A. C. Seward. New York: D. Appleton.

- 1909. The Foundations of the Origin of Species: Two Essays Written in 1842 and 1844. Edited with an Introduction by Francis Darwin. Cambridge: Cambridge University Press.

- 1933. Cherles Darwin's Diary of the Voyage of H.M.S. "Beagle." Edited by Nora Barlow. Cambridge: Cambridge University Press.

- 1945. Charles Darwin and the Voyage of the Beagle. Edited with an Introduction by Nora Barlow. London: Pilot Press.

- 1958[1876]. Autobiography: With Original Omissions Restored. Edited with Appendix and Notes by Nora Barlow. London: Collins.

- 1962[1835]. Coral Islands. With an Introduction, Map, and Remarks by D. R. Stoddart. Atoll Res. Bull., no. 88. Washington, D.C.: National Academy of Sciences.

- 1963[1836]. Darwin's Ornithological Notes. Edited with an Introduction, Notes, and Appendix by Nora Barlow. Bull. Brit. Mus. (Nat. Hist.) Hist. Ser., 2 , no. 7 .

- 1967. Darwin and Henslow: The Growth of an Idea. Letters 1831-1860. Berkeley and Los Angeles: University of California Press.

- 1975[1856-1858]. Charles Darwin's Natural Selection: Being the Second Part of His Big Species Book Written from 1856 to 1858. Edited by R. C. Stauffer. Cambridge: Cambridge University Press.

- 1980[1836-1837]. The Red Notebook of Charles Darwin. Edited with an Introduction and Notes by Sandra Herbert. Bull. Brit. Mus. (Nat. Hist.) Hist. Ser., 7. Published as a book by Cornell University Press, Ithaca, N.Y.

Darwin, Erasmus. 1789. The Botanic Garden; Part I, "The Economy of Vegeta. tion"; Part II, "The Loves of the Plants." London: J. Johnson.

- 1794-1796. Zoonomia; or, The Laws of Organic Life. 2 vols. London: J. Johnson. 
Darwin, Francis, ed. 1887. The Life and Letters of Charles Darwin, Including an Autobiographical Chapter. 3 vols. London: John Muray.

- 1888. "Charles Robert Darwin (1809-1882)." Dictionary of National Biography. Vol. 14, pp: 72-84.

-, ed. 1903. More Letters of Charles Darwin: A Record of His Work in a Series of Hitherto Unpublished Letters. 2 vols. Edited by Francis Darwin and A. C. Seward. New York: D. Appleton.

- 1909. Introduction to The Foundations of the Origin of Species: Two Essays Written in 1842 and 1844, by Charles Darwin (1909). Edited by Francis Darwin. Cambridge: Cambridge University Press.

Davis, John, and Alden H. Miller. 1960. "Family Mimidae." In Check-List of Birds of the World: A Continuation of the Work of James L. Peters. Vol. 9, pp. 440-458. Edited by Ernst Mayr and James C. Greenway, Jr. Cambridge, Mass.: Museum of Comparative Zoology.

de Beer, Gavin. 1958a. "Further Unpublished Letters of Charles Darwin." Ann. Sci., 14:83-115.

- 1958b. Foreword to Evolution by Natural Selection, by Charles Darwin and Alfred Russel Wallace. Cambridge: Cambridge University Press.

-, ed. 1959. Darwin's Journal. Bull, Brit. Mus. (Nat. Hist.) Hist. Ser., 2, no. 1 .

—, ed. 1960-1961. Darwin's Notebooks on Transmutation of Species. Parts I-V. Bull. Brit. Mus. (Nat. Hist.) Hist. Ser., 2, nos. $2-6$.

- 1962. "The Origins of Darwin's Ideas on Evolution and Natural Selection." Proc. Roy. Soc. London. Ser. B. Biol. Sci., 155:321-338.

- 1963. Charles Darwin: Evolution by Natural Selection. London: Thomas Nelson and Sons.

de Beer, Gavin, M. J. Rowlands, and B. M. Skramovsky, eds. 1967. Darwin's Notebooks on Transmutation of Species. Part VI: Pages Excised by Darwin. Bull. Brit. Mus. (Nat. Hist.) Hist. Ser., 3, no. 5.

Dobzhansky, Theodosius, Francisco J. Ayala, G. Ledyard Stebbins, and James W. Valentine. 1977. Evolution. San Francisco: W. H. Freeman.

d'Orbigny, Alcide, and A. de Lafresnaye. 1837. "Synopsis avium." Magasin de Zoologie, 7:188.

Dorst, Jean. 1974. The Life of Birds. 2 vols. Translated by I. C. J. Galbraith. London: Weidenfeld and Nicolson.

Eibl-Eibesfeldt, Irenäus. 1961. Galapagos: The Noah's Ark of the Pacific. Translated by Alan Houghton Brodrick. Garden City, N.Y.: Doubleday.

Eiseley, Loren. 1958. Darwin's Century: Evolution and the Men Who Discovered It. Garden City, N.Y.: Doubleday

Engel, Leonard. 1962. Introduction to The Voyage of the Beagle, by Charles Darwin. Garden City, N.Y.: Anchor Books/Doubleday.

FitzRoy, Robert. 1839. Narrative of the Surveying Voyages of His Majesty's Ships Adventure and Beagle, between the Years 1826 and 1836, Describing Their Examination of the Southern Shores of South America, and the Beagle's Circumnavigation of the Globe. Vol. 2: Proceedings of the Second Expedition, 1831-1836, under the Command of Captain Robert Fitz-Roy, R.N. With Appendix. London: Henry Colburn.

Freeman, R. B. 1978. Charles Darwin: A Companion. Folkestone, England: William Dawson \& Sons. 
Ghiselin, Michael T. 1969. The Triumph of the Darwinian Method. Berkeley and Los Angeles: University of California Press.

- 1971. "The Individual in the Darwinian Revolution." New Lit. Hist., 3:113134.

Gould, John. 1836. "Characters of Some New Species of Birds in the Society's Collection." Proc. Zool. Soc. London, 4:5-7.

- 1837a. "Remarks on a Group of Ground Finches from Mr. Darwin's Collection, with Characters of the New Species." Proc. Zool. Soc. London, 5:4-7.

- 1837b. "Observations on the Raptorial Birds in Mr. Darwin's Collection, with Characters of the New Species," Proc. Zool. Soc. London, 5:9-11.

- 1837c. "Exhibition of the Fissirostral Birds from Mr. Darwin's Collection, and Characters of the New Species." Proc. Zool. Soc. London, 5:22.

- 1837d. "[Exhibition of] Three Species of the Genus Orpheus, from the Galapagos, in the Collection of Mr. Darwin." Proc. Zool. Soc. London, 5:27.

- 1837e. "On a New Rhea (Rheo Darwinii) from Mr. Darwin's Collection." Proc. Zool. Soc. London, 5:35.

- 1841. The Zoology of the Voyage of H.M.S. Beagle, under the Command of Captain FitzRoy, R.N., during the Years 1832-1836. Edited and superintended by Charles Darwin. Part III : Birds. London: Smith, Elder.

Grinnell, George. 1974. "The Rise and Fall of Darwin's First Theory of Transmutation." J. Hist. Biol., 7:259-273.

Gruber, Howard E. 1974. Darwin on Man: A Psychological Study of Scientific Creativity. Together with Darwin's Early and Unpublished Notebooks. Transcribed and annotated by Paul H. Barrett. Foreword by Jean Piaget. New York: E. P. Dutton.

Gruber, Howard E., and Valmai Gruber. 1962. "The Eye of Reason: Darwin's Development during the Beagle Voyage." Isis, 53:186-200.

Grzimek, Bernhard. 1973. Grzimek's Animal Life Encyclopedia. Vol. 9: Birds. New York: Van Nostrand Reinhold.

Haeckel, Ernst. 1876. The History of Creation: Or the Development of the Earth and Its Inhabitants by the Action of Natural Causes. 2 vols. New York: D. Appleton.

Harris, Michael. 1974. A Field Guide to the Birds of the Galapagos. London: William Collins \& Sons.

Herbert, Sandra. 1968. “The Logic of Darwin's Discovery." Ph.D. diss., Brandeis University.

- 1974. "The Place of Man in the Development of Darwin's Theory of Transmutation. Part I. To July 1837." J. Hist. Biol., 7:217-258.

--, ed. 1980. The Red Notebook of Charles Darwin. With an Introduction and Notes. Bull. Brit. Mus. (Nat. Hist.) Hist. Ser., 7. Published as a book by Cornell University Press, Ithaca, N.Y.

Himmelfarb, Gertrude. 1959. Darwin and the Darwinian Revolution. New York: Doubleday.

Huxley, Julian. 1954. "The Evolutionary Process." In Evolution as a Process, pp. 1-23. Edited by Julian Huxley, A. C. Hardy, and E. B. Ford. London: George Allen \& Unwin.

- 1966. "Charles Darwin: Galapagos and After." In The Galapagos, pp. 3-9. Edited by Robert I. Bowman. Berkeley and Los Angeles: University of California Press. 


\section{FRANK J. SULLOWAY}

Huxley, Thomas Henry. 1888. "[Charles Robert Darwin:] Obituary Notices of Fellows Deceased." Proc. Roy. Soc. London, 44 : i-xxv.

Irvine, William. 1955 . Apes, Angels, and Victorians: The Story of Darwin. Huxley, and Evolution. New York: McGraw-Hill.

Jensen, William A., Bernd Heinrich, David B. Wake, Marvalee H. Wake, and Stephen L. Wolfe. 1979. Biology. Belmont, Calif.: Wadsworth.

Judd, John W. 1909. "Darwin and Geology." In Darwin and Modern Science, pp. 337-384. Edited by A.C. Seward. Cambridge: Cambridge University Press.

Kimball, John W, 1978. Biology. 4th ed. Reading, Mass.: Addison Wesley.

Kohn, David. 1980. "Theories to Work By: Rejected Theories, Reproduction, and Darwin's Path to Natural Selection." Stud. Hist. Biol, 4:67-170.

Kottler, Malcolm, J. 1978. "Charles Darwin's Biological Species Concept and Theory of Geographic Speciation: the Transmutation Notebooks." Ann. Sci., 35:275-297.

Kuhn, Thomas S. 1970. The Structure of Scientific Revoltuions. 2nd ed. Chicago: University of Chicago Press.

Lack, David. 1947. Darwin's Finches: An Essay on the General Biological Theory of Evolution. Cambridge: Cambridge University Press.

- 1969. "Subspecies and Sympatry in Darwin's Finches." Evolution, 23:252263.

Leigh, Egbert Giles, Jr. 1971. Adaptation and Diversity: Natural History and the Mathematics of Evolution. San Francisco: Freeman, Cooper.

Limoges, Camille. 1970. La Sélection naturelle: Étude sur lo premiere constitution d'un concept (1837-1859). Paris: Presses Universitaires de France.

Lyell, Charles. 1830-1833. Principles of Geology, Being an Attempt to Explain the Former Changes of the Earth's Surface, by Reference to Causes Now in Operation. 3 vols. London: John Murray.

- 1837. "Address to the Geological Society, Delivered at the Anniversary, on the 17th of February, 1837, by Charles Lyell, Jun., Esq., President." Proc. Geol. Soc. London, 2:479-523.

Martin, William. 1837a. "Observations on Three Specimens of the Genus Felis Presented to the Society by Charles Darwin, Esq., Corr. Memb. Z. S." Proc. Zool. Soc. London, 5:3-4.

- 1837b, "Observations upon a New Fox from Mr. Darwin's Collection (Vulpes fulvipes)." Proc. Zool. Soc. London, 5:11-12.

- 1837c. "Observations on a Specimen of Dasypus hybridus, Desm., from Mr. Darwin's Collection." Proc. Zool. Soc. London, 5:13-14.

Mayr, Ernst. 1947. Review of The Galapagos Finches (Geospizinae) and Darwin's Finches, by David Lack (1945, 1947). Quart. Rev. Biol., 22:217.

Moody, Paul Amos. 1970. Introduction to Evolution. 3rd ed. New York: Harper \& Row.

Moorehead, Alan. 1969. Darwin and the Beagle. New York: Harper \& Row.

Olney, P. J. S. 1976. "The Policy of Keeping Birds in the Society's Collections 1826-1976." Symposia Zool. Soc. London, no. 40:133-145.

Ospovat, Dov. 1981. The Development of Darwin's Theory: Natural History, Natural Theology, and Natural Selection, 1838-1859. Cambridge and New York: Cambridge University Press.

Owen, Richard. 1840. The Zoology of the Voyage of H.M.S. Beagle, under the Command of Captain FitzRoy, R.N., during the Years 1832 to 1836. Edited 
and superintended by Charles Darwin. Vol. 1 : Part I: Fossil Mammalia. With a Geological Introduction by C. Darwin. London: Smith, Elder.

Peterson, Roger Tory. 1963. The Birds. Life Nature Library. New York: Time, Inc.

Porter, David. 1815. Journal of the Cruise Made to the Pacific Ocean, by Captain David Porter, in the United States Frigate Essex, in the Years 1812, 1813, and 1814. Containing Descriptions of the Cape de Verd Islands, Coasts of Brazil, Patagonia, Chili, and Peru, and of the Galapagos Islands. 2 vols. Philadelphia: Bradford and Inskeep.

Poulton, Edward Bagnall. 1910. "Charles Robert Darwin (1809-1882)." In Encyclopedic Britannica. 11 th ed. Vol. 7, pp. 840-843.

Ralling, Christopher, producer. 1978. The Voyage of Charles Darwin. A sevenpart film depicting the life of Charles Darwin. Written by Robert Reid. British Broadcasting Corporation.

Reid, James. 1837. "Notes on Several Quadrupeds in Mr. Darwin's Collection." Proc. Zool. Soc. London, $5: 4$.

[Rossetti, Geoffrey W.] 1930. "A Letter of Charles Darwin." Cambridge Review, $60: 410$.

Ruse, Michael. 1979. The Darwinian Revolution: Science Red in Tooth and Claw. Chicago and London: University of Chicago Press.

Silverstein, Alvin. 1974. The Biological Sciences. San Francisco: Holt, Reinhart, and Winston.

Smith, Sydney. 1960. "The Origin of 'the Origin' as Discerned from Charles Darwin's Notebooks and His Annotations in the Books He Read between 1837 and 1842."Advance. Sci., 16:391401.

Sowerby, James de Carle. 1837. "A Communication by Mr. James de Carle Sowerby, on His New Genus of Fossil Shells, Tropaum." Proc. Geol, Soc. London, 2:535.

Sulloway, Frank J. 1969. "Charles Darwin and the Voyage of the Beagle (18311836)," Senior honors thesis, Harvard College.

- 1979. "Geographic Isolation in Darwin's Thinking: The Vicissitudes of a Crucial Idea." Stud. Hist. Biol., 3:23-65.

- 1982a. "Darwin and His Finches: The Evolution of a Legend." J. Hist. Biol., 15:1-53.

- 1982b. The Beagle Collections of Darwin's Finches (Geospizinae). Bull. Brit. Mus. (Nat. Hist.) Zool. Ser., 43, no. 2:49-94.

- in press. "Darwin's Early Intellectual Development: An Overview of the Beagle Voyage (1831-1836)." In The Darwinian Heritage: A Centennial Retrospect. Edited by David Kohn. Princeton: Princeton University Press.

Swarth, Harry S. 1931. The Avifaune of the Galapagos Islands. Occ. Pap. Calif. Acad. Sci., no. 18.

Thompson, Richard F. 1975. Introduction to Physiological Psychology. New York: Harper \& Row.

Thomton, Ian. 1971. Darwin's Islands: A Natural History of the Galápagos. Garden City, N.Y.: Natural History Press.

Waterhouse, George Robert. 1837a. "Characters of New Species of the Genus Mus, from the Collection of Mr. Darwin." Proc. Zool. Soc. London, 5:15-21.

- 1837b. "Characters of New Species of the Genus Mus, from the Collection of Mr. Darwin." Proc. Zool. Soc. London, 5:27-32. 


\section{FRANK J. SULLOWAY}

Whewell, William. 1838. "Address to the Geological Society, Delivered at the Anniversary, on the 16th of February, 1838, by the Rev. William Whewell, M.A. F.R.S. President of the Society." Proc. Geol. Soc. London, 2:624-649.

Wichler, Gerhard. 1961. Charles Danwin: The Founder of the Theory of Evolution and Natural Selection. New York: Pergamon Press.

Wilson, Leonard G. 1972. Charles Lyell. Vol. 1: The Years to 1841: The Revolution in Geology. New Haven and London: Yale University Press.

Wynne-Edwards, V. C. 1947. Review of Darwin's Finches, by David Lack (1947). Ibis, 89:685-687.

Zoological Society of London. 1838. Reports on the Council and Auditors of the Zoological Society of London. London: Richard and John E. Taylor. 